\title{
Intraplate deformation and microplate tectonics of the Yellowstone hot spot and surrounding western U.S. interior
}

\author{
C. M. Puskas ${ }^{1}$ and R. B. Smith ${ }^{1}$ \\ Received 18 July 2008; revised 29 January 2009; accepted 13 February 2009; published 22 April 2009.
}

[1] Contemporary deformation of the Yellowstone hot spot and surrounding western United States is analyzed using tectonic microplate modeling, employing constraints from GPS observations corrected for postseismic deformation of $M 7+$ earthquakes, fault slip rates, and earthquake focal mechanisms. We focus primarily on the kinematics of the Yellowstone hot spot and the eastern Snake River Plain volcanic field (ESRP), and secondarily on Basin-Range and Columbia Plateau provinces. Our results reveal southwest motion of the Yellowstone Plateau, excluding localized volcanic deformation, at $0.9 \pm 0.1 \mathrm{~mm} / \mathrm{a}$ that decreases to $0.8 \pm 0.1 \mathrm{~mm} / \mathrm{a}$ in the ESRP block. The southwest to west motion of the Yellowstone-ESRP introduces shear in the northern Rocky Mountain block, which is translating east at $0.78 \pm 0.08 \mathrm{~mm} / \mathrm{a}$. There is $<0.5 \mathrm{~mm} / \mathrm{a}$ differential motion between the ESRP and the block at its northern boundary and none at the southern boundary. The eastern Basin-Range block moves west at $3.0 \pm 0.1$ to $4.6 \pm 0.1 \mathrm{~mm} / \mathrm{a}$, while velocities of the western Basin-Range microplates rotate to a northwest direction, accompanied by a transition from normal to oblique shear deformation. Columbia Plateau block velocities are notably eastward, an effect enhanced by postseismic relaxation following the M9 1700 Cascadia subduction zone paleoearthquake. This study reveals that the overall motion of the western United States is characterized by clockwise rotation, with westward extension and northwest shear in the Basin-Range province, northeast to east contraction in the Columbia Plateau, and southwest extension of the YellowstoneSnake River Plain block that is driven by the high gravitational potential of the Yellowstone swell.

Citation: Puskas, C. M., and R. B. Smith (2009), Intraplate deformation and microplate tectonics of the Yellowstone hot spot and surrounding western U.S. interior, J. Geophys. Res., 114, B04410, doi:10.1029/2008JB005940.

\section{Introduction}

[2] The western United States interior is a region of intraplate Cenozoic deformation and widespread volcanism between the Rocky Mountains and the Sierra NevadaCascade Ranges (Figure 1). It is characterized by distinct tectonic provinces that reflect a complex geologic history and interaction of tectonic and volcanic processes. These include the Yellowstone hot spot and the Snake River Plain volcanic field, the Basin-Range province (also called the Basin and Range province), the Columbia Plateau volcanic province, and the northern Rocky Mountains. Within the interior region, the Yellowstone hot spot is a major volcanic feature. The hot spot is associated with a mantle plume that has interacted with the overriding lithosphere to produce a series of time-progressive silicic volcanic centers along the hot spot track of the eastern Snake River Plain (ESRP) (see summary of Yellowstone plume dynamics by Smith et al. [2009]). In conjunction with volcanism, the Yellowstone hot

\footnotetext{
${ }^{1}$ Department of Geology and Geophysics, University of Utah, Salt Lake City, Utah, USA.

Copyright 2009 by the American Geophysical Union. 0148-0227/09/2008JB005940\$09.00
}

spot is characterized by high heat flow in excess of $1500 \mathrm{~mW} \mathrm{~m}^{-2}$ [Blackwell and Richards, 2004], $300 \mathrm{~m}$ of excess elevation associated with a $600-\mathrm{km}$-wide topographic swell, and the largest geoid anomaly in continental North America, $\sim 12 \mathrm{~m}$ above background [Smith and Braile, 1994].

[3] The volcanic processes and plume-plate interactions of the Yellowstone hot spot affect deformation within the western interior including alignments of earthquake [Smith and Sbar, 1974], modification of crustal composition and strength [DeNosaquo and Smith, 2009], and variations in tectonic deviatoric stresses [Humphreys and Coblentz, 2007; Puskas et al., 2007a]. With the increasing availability of GPS measurements as well as new compilations of Late Quaternary fault data and historic earthquake information, it has become possible to evaluate the large-scale contemporary deformation of the western interior and to relate it to the driving mechanisms of this large intraplate regime.

[4] In this paper we model deformation using a microplate block parameterization [McCaffrey, 2002]. Block boundaries are identified by earthquake zones, active faults, and variations in GPS velocity magnitude and direction. In addition, to determine long-term deformation, the GPS velocity data were corrected for the effects of postseismic deformation from large, $M>7$ earthquakes in the western 


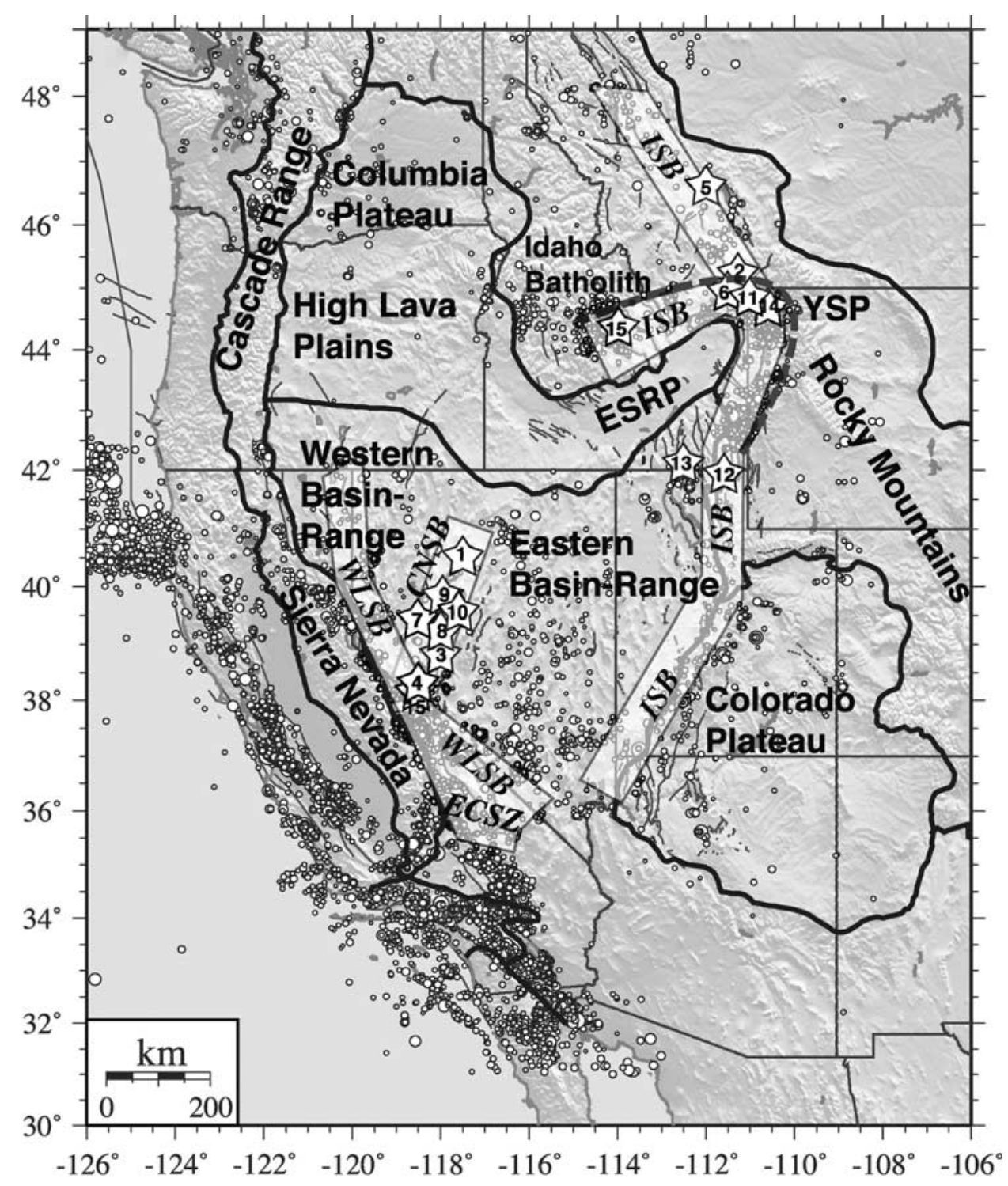

Figure 1. Index map of the western United States showing topography, tectonic provinces (heavy solid lines), $M>3$ earthquakes (white circles), and major faults (black lines). The central Nevada seismic belt (CNSB), Walker Lane seismic belt (WLSB), and Intermountain seismic belt (ISB) are highlighted in white shaded areas. YSP, Yellowstone Plateau, and ESRP, eastern Snake River Plain. The Yellowstone tectonic parabola includes the central ISB adjacent to the SRP and its outer perimeter is represented by the heavy dashed line. Significant $(M>6)$ earthquakes used to infer slip directions are marked with stars (see Table 1).

United States [Hammond and Thatcher, 2005; Pollitz et al., 2008; W. L. Chang and R. B. Smith, Lithospheric rheology from postseismic deformation of a $M=7.5$ normal-faulting earthquake with implications for continental kinematics, unpublished manuscript, 2007].

[5] Our primary objective is to employ microplate modeling to examine the kinematics of the YSRP volcanic system. The relative motions between the Yellowstone Plateau, the seismically quiescent eastern Snake River Plain, and the adjacent seismically active Basin-Range-type terrain are poorly understood, and GPS data have only become available in the last few years [Chadwick et al., 2007; Payne et al., 2007; Puskas et al., 2007b]. Moreover, the Yellowstone Plateau, while strongly influenced by local volcanic deformation, is also experiencing regional lithospheric extension. Using block modeling, we calculated the variations in direction and magnitude of ground motion and relations between the ESRP, Yellowstone Plateau, Basin-Range, and Rocky Mountains.

[6] A secondary goal of our study is to identify subblocks within the Basin-Range province and Columbia Plateau volcanic field. With our compilation of over 2000 GPSderived velocity vectors, we have sufficient data to model the entire western interior. We verified our results through comparisons with other kinematic deformation studies (e.g., see McCaffrey [2005] for the southwestern United States and McCaffrey et al. [2007] for the Pacific Northwest). By examining the larger area of the western interior, we can 
evaluate the contributions of Yellowstone hot spot-related deformation with regional patterns of tectonic driven deformation.

[7] Microplate-bounding faults were modeled by standard dislocation methods [Okada, 1985] assuming an elastic upper layer and creeping lower layer to simulate locking and elastic loading. While the microplates are normally expected to behave rigidly with no long-term internal strain [McCaffrey, 2002], we explored internal block strain to account for unmodeled but active faults.

[8] The microplate modeling approach employed here contrasts with continuum models of deformation that interpolate deformation [e.g., Flesch et al., 2007; Puskas et al., $2007 \mathrm{a}$. It can be argued that the permanent deformation of the lithosphere is due to cumulative slip on faults from earthquakes [Savage et al., 1999], and both methodologies have their advantages [Thatcher, 1995]. Continuum modeling is applicable for regions where deformation is distributed across closely spaced faults, but tends to smooth deformation over large areas. Block modeling constrains deformation to distinct boundary zones and can resolve fault parameters if detailed parameterization is employed and sufficient data are available. The two approaches are complementary; we examine continuum models in an alternate study [Puskas et al., 2007a].

\section{Late Cenozoic Tectonics of the Western U.S. Interior}

[9] The western U.S. interior as defined in this study encompasses the Basin-Range province, the combined Yellowstone-Snake River Plain volcanic field (YSRP), the Columbia Plateau, and the normal fault zones in northern Idaho and western Montana (Figure 1). The western margin of our study area is marked by the transition to the rapidly deforming plate boundaries of the Cascadia subduction zone and San Andreas transform fault.

[10] At large scales, North America-Pacific interplate interactions produce right-lateral shear deformation on the San Andreas and subsidiary faults, while North AmericaJuan de Fuca interactions result in oblique convergence in the Pacific Northwest [e.g., Atwater, 1970; Gan et al., 2000; McCaffrey et al., 2000]. The influence of shear stresses associated with the San Andreas fault extend eastward into the western Basin-Range [Thatcher, 2003], leading to a regime of oblique strike-slip faulting in the Walker Lane seismic belt in western Nevada (Figure 1). Further north, stress interaction of the subducting Juan de Fuca plate beneath the overriding North America plate produces an eastward component of ground motion associated with the Columbia Plateau at least as far as eastern Washington and Oregon [McCaffrey et al., 2000, 2007; Wang et al., 2003].

[11] However, diffuse extension on multiple faults dominates most of the Basin-Range (Figure 1). The extension is thought to be associated with the development of the San Andreas transform boundary between the Pacific and North America plates beginning at $30 \mathrm{Ma}$ [Atwater and Stock, 1988], which allowed the gravitational collapse of previously thickened lithosphere [e.g., Sonder and Jones, 1999].

[12] The Basin-Range is tectonically distinguished by north trending, normal fault-bounded ranges separated by sedimentary basins at an average $25-\mathrm{km}$ spacing [Eddington et al., 1987; Pancha et al., 2006; Smith and Bruhn, 1984]. This distinctive topography extends $\sim 800 \mathrm{~km}$ west from the Wasatch Front, Utah, to the Sierra Nevada of California, and over $2000 \mathrm{~km}$ from Mexico northward into western Montana [Dickinson, 2002] (Figure 1). For the purposes of this study, we examine only the Basin-Range in Nevada and Utah and refer to this area as the Basin-Range (as opposed to the larger province). Although normal faulting extends to the north of the ESRP [Eaton, 1988], these faults are considered part of the northern Rocky Mountains. The Basin-Range is further subdivided into eastern and western parts, with active seismicity at the east-west transition, the central Nevada seismic belt.

[13] A significant influence on large-scale deformation of the western United States is the widespread Late Cenozoic volcanism and related tectonism associated with the Yellowstone hot spot. Basaltic volcanism began $17 \mathrm{Ma}$ with the eruption of the Columbia Plateau flood basalts [Camp and Ross, 2004] and continued with the subsequent bimodal rhyolite-basalt, age-progressive eruptions in the YSRP volcanic province [Perkins and Nash, 2002; Smith and Braile, 1994] and Newberry volcanic field [Jordan et al., 2004]. An upper mantle plume has been identified from seismic tomography as the source of the hot spot [Jordan et al., 2005; Smith et al., 2009; Waite et al., 2006; Yuan and Dueker, 2005]. The hot spot source has produced a $\sim 600-\mathrm{km}$-wide and 300-m-high topographic swell [Smith and Braile, 1994], and hot spot volcanism has reworked the lithosphere through melting and magmatic injection [Carlson and Hart, 1988; Nash et al., 2006; DeNosaquo and Smith, 2009]. The ESRP is the track of hot spot, with the inception of caldera-forming volcanism beginning $\sim 17 \mathrm{Ma}$, while the Yellowstone Plateau (YSP) is the center of current hot spot volcanism that began $2 \mathrm{Ma}$. The ESRP and YSP together comprise the YSRP and are distinct from the western Snake River Plain, a northwest trending graben in western Idaho.

[14] Seismicity of the western U.S. interior is concentrated in distinct seismic belts (Figure 1) that are generally along the Basin-Range province boundaries. These include the Intermountain seismic belt (ISB) to the east, the central Nevada seismic belt in the middle, and the Walker Lane seismic belt to the west. The Yellowstone "tectonic parabola" is an arcuate region of earthquakes and active faulting that surrounds the YSRP and is part of the ISB [Smith and Braile, 1994; Smith and Sbar, 1974; Stickney and Bartholemew, 1987]. Earthquakes in the Basin-Range exhibit normal to oblique-slip focal mechanisms, with shallow focal depths extending to $\sim 20 \mathrm{~km}$ that typically rupture planar faults dipping at average values of $55^{\circ}$ [Doser and Smith, 1989].

[15] Several large, $M 7+$ historic earthquakes have occurred in the study area (Table 1). These include the 1915 M7.1 Pleasant Valley, Nevada, and 1954 M5.5-7.2 Rainbow Mountain-Fairview Peak-Dixie Valley, Nevada, earthquakes. The largest events in the Intermountain region were the 1959 M7.5 Hebgen Lake, Montana, earthquake and the 1983 M7.3 Borah Peak, Idaho, earthquake. The Wasatch fault zone in Utah has been historically quiescent, but is considered capable of producing $M 7.5$ earthquakes based on paleoseismic studies of Late Quaternary fault slip [McCalpin and Nishenko, 1996; Chang and Smith, 2002]. 
Table 1. Earthquakes and Focal Mechanisms of the Western U.S. Interior That Were Used to Infer Slip Azimuths

\begin{tabular}{|c|c|c|c|c|}
\hline Earthquake & Date & Magnitude & Type & Slip Azimuth \\
\hline Pleasant Valley, Nevada & 1915 & $M=7.1$ & normal & $246^{\circ} \pm 56$ \\
\hline Clarkston, Montana & 1925 & $M_{w}=6.6$ & oblique normal & $237^{\circ} \pm 7$ \\
\hline Cedar Mountain, Nevada & 1932 & $M_{w}=6.8$ & strike-slip & $359^{\circ} \pm 5$ \\
\hline Excelsior Mountain, Nevada & 1934 & $M_{w}=6.1$ & normal & $339^{\circ} \pm 40$ \\
\hline Helena, Montana & 1935 & $M=6.3$ & strike-slip & $263^{\circ} \pm 24$ \\
\hline Virginia City, Montana & 1947 & $M_{w}=6.1$ & oblique normal & $277^{\circ} \pm 8$ \\
\hline Rainbow Mountain, Nevada & 1954 & $M_{w}=6.1$ & oblique strike-slip & $327^{\circ} \pm 7$ \\
\hline Fairview Peak, Nevada & 1954 & $M_{w}=7.2$ & strike-slip & $339^{\circ} \pm 8$ \\
\hline Dixie Valley, Nevada & 1954 & $M_{w}=6.7$ & normal & $270^{\circ} \pm 45$ \\
\hline Dixie Valley, Nevada & 1959 & $M=6.3$ & strike-slip & $3^{\circ} \pm 17$ \\
\hline Hebgen Lake, Montana & 1959 & $M=7.5$ & normal & $185^{\circ} \pm 8$ \\
\hline Logan, Utah & 1962 & $M_{w}=5.9$ & normal & $317^{\circ} \pm 16$ \\
\hline Pocatello Valley, Idaho & 1974 & $M_{w}=6.2$ & normal & $265^{\circ} \pm 34$ \\
\hline Norris, Wyoming & 1975 & $M_{L}=6.1$ & oblique normal & $245^{\circ} \pm 18$ \\
\hline Borah Peak, Idaho & 1983 & $M_{s}=7.3$ & normal & $189^{\circ} \pm 6$ \\
\hline
\end{tabular}

Rupture geometries inferred from focal mechanisms for these large earthquakes [Doser and Smith, 1989; Pitt et al., 1979] were used also to constrain slip directions in our models.

[16] Large earthquakes contribute to regional deformation through coseismic fault slip, but they are also sources of time-dependent postseismic relaxation that can affect ground motions and thus GPS measurements for decades after the earthquakes [Gourmelen and Amelung, 2005; Hammond et al., 2009; Pollitz, 2003; Pollitz et al., 2008; W. L. Chang and R. B. Smith, unpublished manuscript, 2007]. Additionally, very large paleoearthquakes outside the study area can also affect regional deformation (Table 2) [Pollitz et al., 2008].

\section{Tectonic Modeling of the Western U.S. Interior 3.1. Methodology}

[17] This study follows the methodology described by McCaffrey [2002] for modeling the kinematics of microplates. GPS-determined velocity vectors, Late Quaternary fault slip rates, and earthquake slip azimuths were used to constrain rigid block rotations and relative motion between blocks.

[18] In the block model, the $p$ th block rotates about an Euler pole $\Omega_{\mathrm{p}}=\left(\lambda_{\mathrm{p}}, \phi_{\mathrm{p}}, \omega_{\mathrm{p}}\right)$ at latitude $\lambda_{\mathrm{p}}$, longitude $\phi_{\mathrm{p}}$, and angular velocity $\omega_{\mathrm{p}}$ [McCaffrey, 2002]. A point $\vec{x}$ with coordinates $(\lambda, \phi)$ on the block has a velocity of

$$
\mathrm{V}_{\mathrm{p}}(\overrightarrow{\mathrm{x}})=\Omega_{\mathrm{p}} \times \overrightarrow{\mathrm{x}}
$$

Equation (1) assumes that a given block rotates freely, without fault locking. By placing faults at block boundaries, the relative motions between blocks can be constrained. Components of the point vector $\vec{x}$ are latitude and longitude in a spherical coordinate system.

[19] The velocity $\mathrm{V}(\vec{x})$ at point $\vec{x}$ within a block will also be affected by fault loading. To account for this, we introduce the backslip velocity, which has motion opposite in direction to block rotation [Savage, 1983; McCaffrey, 2002]. The back-slip term for the $k$ th fault is given by

$$
V_{b s}(\vec{x})=-\sum_{n=1}^{N_{k}} \sum_{j=1}^{2}\left\{\Phi_{n} G_{i j}\left(\vec{x}, \vec{x}_{n}\right)\left[{ }_{h} \Omega_{f} \times \vec{x}_{n}\right] \cdot \vec{u}\right\},
$$

where $\Phi_{n}$ is a parameter describing the amount of locking at the $n$th of $N_{k}$ nodes on fault $k, G_{i j}$ is the Green's function relating the $i$ th component of surface velocity at $\vec{x}$ to slip on the fault at $\vec{x}_{\mathrm{n}}$ in the $j$ th direction, ${ }_{h} \Omega_{f}$ is the relative pole of rotation between the hanging wall and footwall, and $\vec{u}$ is a unit vector on the fault surface with components for alongstrike and downdip directions. The locking parameter $\Phi$ defines whether a fault slips freely $(\Phi=0)$ or is locked $(\Phi=$ $1)$. For our models, faults are either completely locked or completely free. The locked faults are parameterized to have $\Phi=1$ in the upper, elastic layer and $\Phi=0$ in the lower crust. The geometry of a locked fault with slipping lower layer is illustrated in Figure 2. Green's functions are calculated according to the analytical expressions described by Okada [1985] and relate the surface deformation in response to a unit dislocation at each node of each fault. An elastic halfspace is assumed for the Earth when determining the Green's functions.

[20] If permanent strain is allowed within a block, then the strain-produced velocity components at point $\vec{x}$ are

$$
\begin{aligned}
& V_{\varepsilon \phi}(\vec{x})=\dot{\varepsilon}_{\phi \phi} R_{E} \sin \theta_{0}\left(\phi-\phi_{0}\right)+\dot{\varepsilon}_{\phi \lambda} R_{E}\left(\lambda-\lambda_{0}\right) \\
& V_{\varepsilon \lambda}(\vec{x})=\dot{\varepsilon}_{\phi \lambda} R_{E} \sin \theta_{0}\left(\phi-\phi_{0}\right)+\dot{\varepsilon}_{\lambda \lambda} R_{E}\left(\lambda-\lambda_{0}\right),
\end{aligned}
$$

where $\phi$ and $\lambda$ are the longitude and latitude components of the position vector $\vec{x}, \dot{\varepsilon}_{i j}$ is the horizontal strain rate tensor, $R_{E}$ is the radius of the Earth, and $\left(\lambda_{0}, \phi_{0}\right)$ are the block

Table 2. List of Earthquakes Used in Modeling of Postseismic Viscoelastic Velocities

\begin{tabular}{lcc}
\hline \multicolumn{1}{c}{ Earthquake } & Year & Magnitude \\
\hline Cascadia & 1700 & 9.1 \\
Fort Tejon, California & 1857 & 8.0 \\
Owens Valley, California & 1972 & 7.6 \\
San Francisco, California & 1906 & 8.0 \\
Pleasant Valley, Nevada & 1915 & 7.7 \\
Cedar Mountain, Nevada & 1932 & 7.1 \\
Kern County, California & 1952 & 7.2 \\
Fairview Peak, Nevada & 1954 & 7.2 \\
Dixie Valley, Nevada & 1954 & 7.1 \\
Hebgen Lake, Montana & 1959 & 7.5 \\
Borah Peak, Idaho & 1983 & 7.3 \\
Loma Prieta, California & 1989 & 6.9 \\
Landers, California & 1992 & 7.3 \\
\hline
\end{tabular}


a)

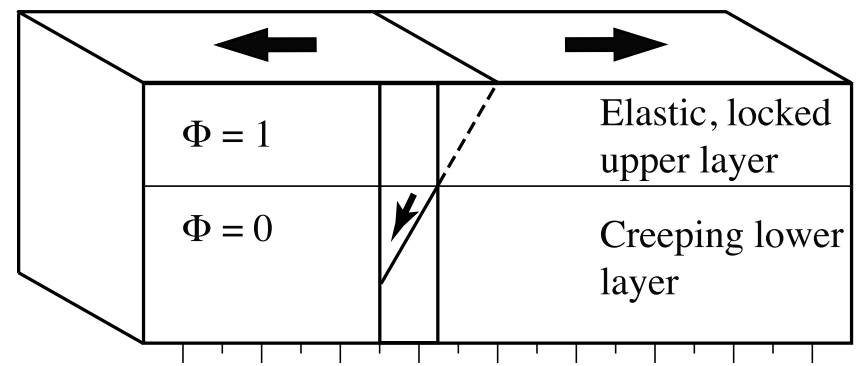

b)

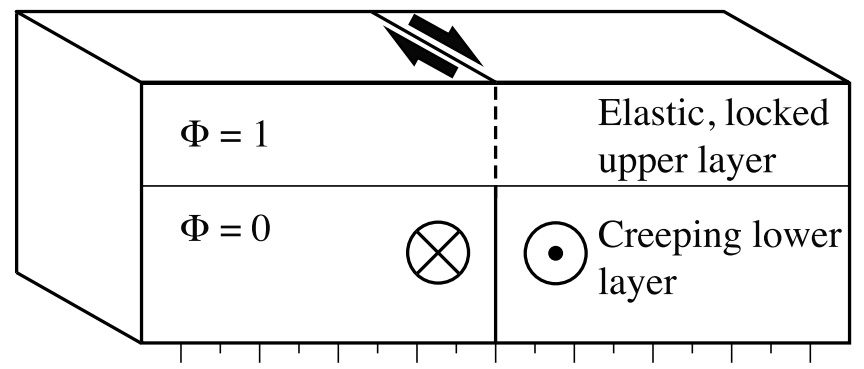

Figure 2. Parameterization of block-bounding faults for (a) normal faults and (b) strike-slip faults. Both fault types are locked in the elastic upper layer and slipping in the ductile lower layer. Surface velocities are the result of a dislocation on the slipping lower layer of the fault.

centroid coordinates [McCaffrey, 2005]. The strain rate tensor is derived from the strain equations for a spherical Earth from Savage et al. [2001].

[21] The total velocity at any position on a block is then the combination of the rotation, backslip, and internal strain from equations (1), (2), and (3). Thus the total velocity will be

$$
V_{\text {total }}(\vec{x})=V_{p}(\vec{x})+V_{b s}(\vec{x})+V_{\varepsilon}(\vec{x}) .
$$

[22] Our goal is to determine the centroid velocity of each block and strain rate tensors for selected blocks. To do this, we digitize a set of blocks to represent the western U.S. interior tectonic provinces (Figure 3). The poles of rotation of all the blocks, the rotations required to transform GPS data sets into the model reference frame, fault parameters, and strain rate tensors are all estimated using a downhill simplex methodology [Press et al., 1992]. The algorithm minimizes the chi-square $\left(\chi^{2}\right)$ parameter and the residuals between observed and modeled data. The reduced $\chi^{2}$ parameter is a statistical value that calculates the quality of a solution given by

$$
\chi^{2}=\frac{1}{\operatorname{dof}} \sum_{i}\left(\frac{r_{i}}{f \sigma_{i}}\right)^{2},
$$

where dof is the degrees of freedom and $r_{\mathrm{i}}$ is the $i$ th residual, $f$ is a scaling factor, and $\sigma_{i}$ is the uncertainty for the $i$ th datum [McCaffrey, 2005]. The scaling factor $f$ is set to 1 for our models. The residual is

$$
r_{i}\left(\vec{x}_{i}\right)=V_{\mathrm{obs}}\left(\vec{x}_{i}\right)-V_{\text {mod }}\left(\vec{x}_{i}\right),
$$

where $V_{\text {obs }}\left(\vec{x}_{i}\right)$ is the observed GPS velocity and $V_{\text {mod }}\left(\vec{x}_{i}\right)$ is the model velocity at the point $\vec{x}_{i}$ from equation (4) for total velocity.

[23] The downhill simplex algorithm minimizes an $N$ dimensional function by constructing a simplex, which is a geometric volume of $N+1$ dimensions consisting of the function evaluated at $N+1$ parameters [Nelder and Meade, 1965]. The vertices of the simplex are then searched for the worst solution point, which is then modified and reevaluated. The algorithm attempts to bracket the best solution by moving the simplex downhill in solution space. The simplex is evaluated iteratively, so that the modified simplex of one step is used to start the next implementation to avoid local minima and obtain a global minimum. After 200 to 500 iterations, the algorithm tends to converge to a stable solution, with little or no change in the $\chi^{2}$ statistic between iterations (Figure 4).

\subsection{Ground Motion Data}

\subsubsection{GPS Measurements}

[24] GPS data from over 2000 sites were compiled for the western United States from campaign and permanent station deployments (Figure 5 and Table 3). These included GPS measurements for the YSRP and northern Rocky Mountains [Chang, 2004; Chadwick et al., 2007; Payne et al., 2008; Puskas et al., 2007b], the Wasatch Front, Utah [Chang, 2004], the Basin-Range [Bennett et al., 2003; Chang, 2004; Hammond and Thatcher, 2005; Hammond and Thatcher,

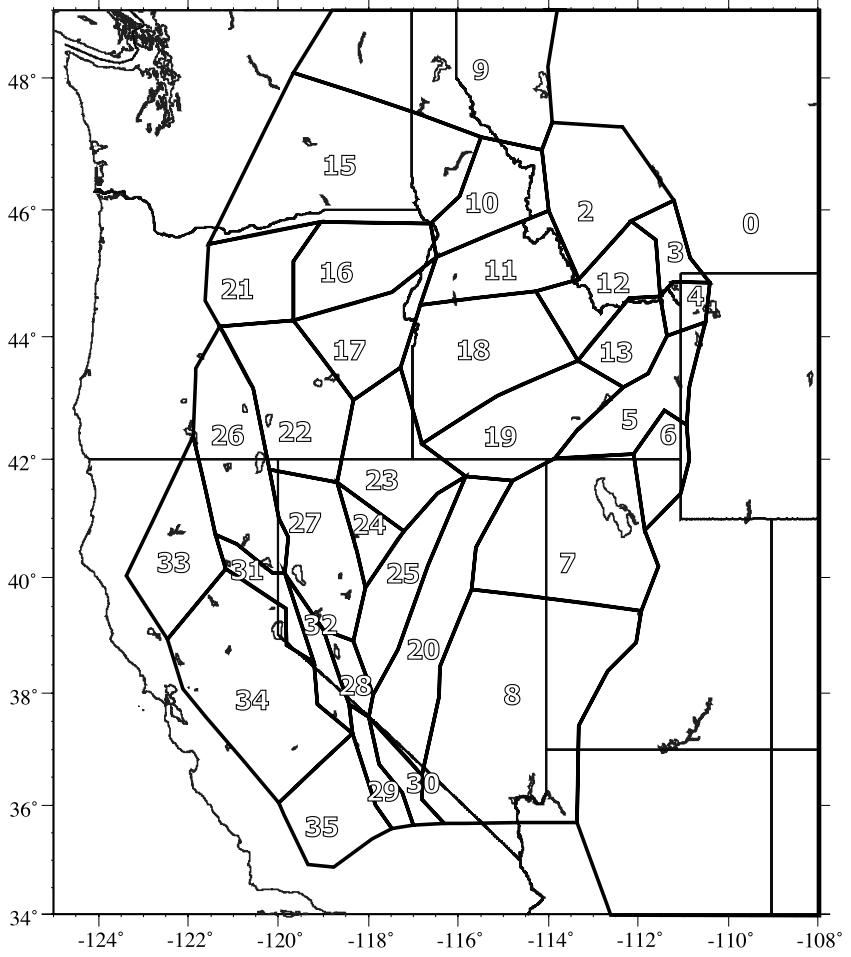

Figure 3. Block distribution and block numbers used for modeling. Block 0 corresponds to stable North America. 

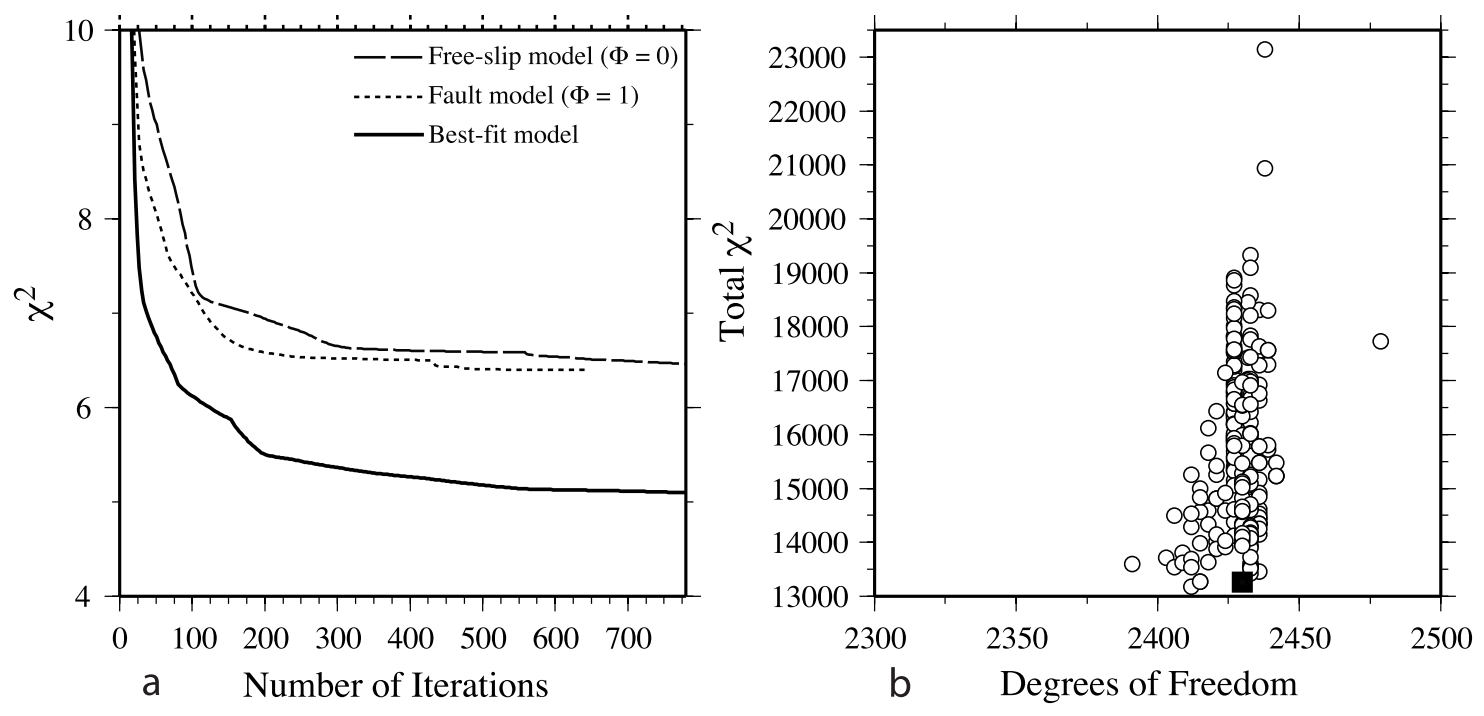

Figure 4. (a) Reduced $\chi^{2}$ value versus number of iterations for the free-slip and fault models as well as the best fit model, and (b) total $\chi^{2}$ value versus the degrees of freedom for each model run. The total $\chi^{2}$ value does not depend strongly on the degrees of freedom. The best fit, preferred model is shown as the black square.

2007; Svarc et al., 2002; Thatcher et al., 1999], and the Pacific Northwest [Hammond and Thatcher, 2007]. We also included velocities from GPS stations of the Plate Boundary Observatory (G. Anderson et al., Plate Boundary Observatory data management system critical design review version 1.2, 2006, available at http://pboweb.unavco.org/) and from the USGS Earthquake Hazards Program (http:/quake. wr.usgs.gov/research/deformation/gps/auto/CL.html). Much of the data for the central and western Idaho are from Payne et al. [2008], who incorporated data from the High Accuracy Reference Network (HARN) GPS campaign of 1999 by the National Geodetic Survey.

[25] The GPS velocity vectors were primarily determined in the North America-fixed reference frame where horizontal velocities are calculated with respect to the North America interior, which is assumed to be nondeforming. We defined the stable North America interior as the region east of the Basin-Range that includes the Colorado Plateau and most of the Rocky Mountains. For our models, the fixed interior is identified as block 0 (Figure 3). Two of the data sets were in their own local reference frame, where one or more stations in a network had their coordinates and velocities fixed, and the remaining stations had their motions calculated relative to the fixed stations. All data sets were individually rotated into the model reference frame to avoid bias from different formulations of the North America reference frame [McCaffrey, 2005] (Figure 5).

[26] The GPS data were examined for outliers prior to inclusion in the modeling. Outliers included velocity vectors from known short-term volcanic sources, fixed-velocity stations, and vectors significantly different from neighboring sites. GPS site velocities associated with volcanically related deformation of the Yellowstone volcanic field [Puskas et al., $2007 b]$ were excluded from our data. Similarly, studies of ground motion at the late Quaternary, 0.74 Ma Long Valley caldera, California [Langbein, 2003], were not included in our modeling. Fixed station data were removed because their uncertainties were set to zero, making them unusable in equation (5). After filtering and removing sites outside the study area, 1261 GPS vectors were used.

[27] Because the GPS data were compiled from multiple studies, error calculations for each data set differed. We evaluated this effect by comparing the mean uncertainties of the various GPS data sets (Table 3). For example, the Teton fault, Wyoming, and Wasatch fault, Utah, data sets had the lowest mean errors of 0.27 and $0.13 \mathrm{~mm} / \mathrm{a}$, respectively. The low errors of these networks were attributed to the use of fixed stations whose errors were set to zero when determining the relative network velocities. The use of fixed stations had the effect of reducing errors of the rest of the network sites as an artifact of the velocity calculations. The more typical range of mean errors was 0.42 to $2.88 \mathrm{~mm} / \mathrm{a}$ (Table 3 ).

\subsubsection{Postseismic Viscoelastic Deformation}

[28] The lower crust and upper mantle flows viscoelastically in response to fault slip from a large earthquake in the overlying brittle layer. This effect introduces a time-varying component to the total deformation field that can last for tens to hundreds of years after the event. We corrected for the effects of postseismic viscoelastic deformation associated with large historic earthquakes of the region of magnitudes $6.5<M<\sim 9$.

[29] The postseismic correction is intended to create an approximation of the long-term deformation rate. While the original GPS data provide a snapshot of contemporary deformation, such data does not account for transient motions following large earthquakes. The magnitude of transient effects depends primarily on the earthquake magnitude.

[30] Postseismic effects have been identified from geodetic data of the 1983 M7.3 Borah Peak, Idaho, earthquake, the 1959 M7.5 Hebgen Lake, Montana, earthquake [Holdahl and Dzurisin, 1991; Nishimura and Thatcher, 2003], for M6.57.7 earthquakes of the central Nevada seismic belt and eastern California [Gourmelen and Amelung, 2005; Hammond, 2005], historic California earthquakes [Pollitz, 2001], and the prehistoric Cascadia subduction zone earthquake in the Pacific Northwest [Pollitz et al., 2008] (Table 2). 


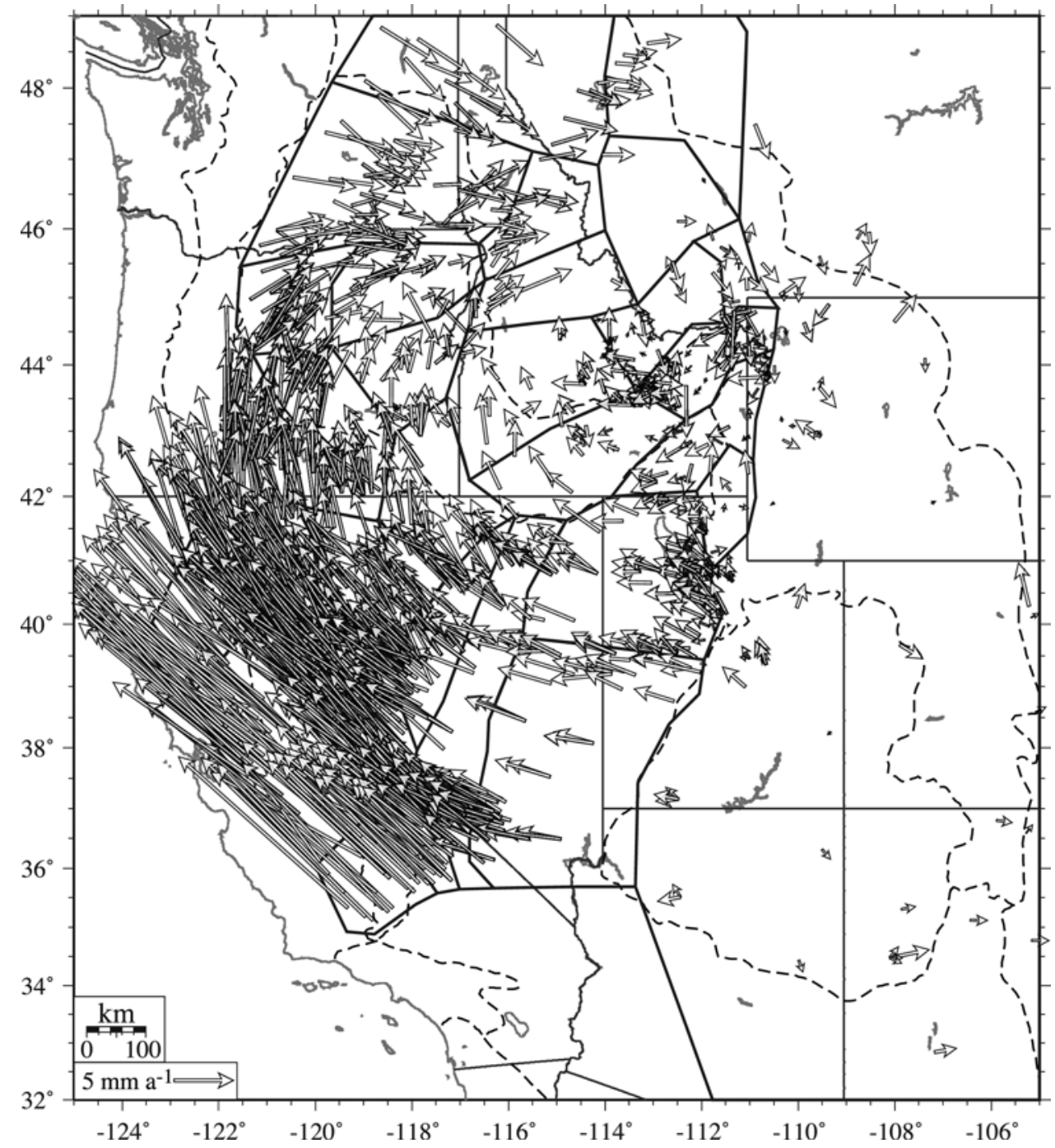

Figure 5. GPS site velocities used in our block modeling. Tectonic provinces are marked with dashed lines and block boundaries with heavy, black lines. GPS-derived velocities were corrected for postseismic deformation and transformed into the model reference frame prior to plotting.

[31] The postseismic velocities of Pollitz et al. [2008] and W. L. Chang and R. B. Smith (unpublished manuscript, 2007) for the Intermountain region were combined into a single velocity field (Figure 6). The postseismic velocity field is the combination of effects of all earthquakes in the seismic cycle but is dominated by recent, large earthquakes [Pollitz et al., 2008]:

$$
\begin{aligned}
V_{p s}(\vec{x})= & \sum_{n} \int_{\Gamma_{n}} d^{3} \vec{x}_{0} m\left(\vec{x}_{0}\right): \sum_{j \geq 0} \dot{G}\left(\vec{x}, \vec{x}_{0}, t-t_{n}+j T_{n}\right) \\
& +\sum_{m} \int_{\Gamma_{m}} d^{3} \vec{x}_{0} \dot{m}_{\text {fault }}\left(\vec{x}_{0}\right):\left[G\left(\vec{x}, \vec{x}_{0}, \infty\right)-G\left(\vec{x}, \vec{x}_{0}, 0\right)\right] \\
& +\int_{V-\Gamma_{m}} d^{3} \vec{x}_{0} \dot{m}_{V}\left(\vec{x}_{0}\right):\left[G\left(\vec{x}, \vec{x}_{0}, \infty\right)-G\left(\vec{x}, \vec{x}_{0}, 0\right)\right] \\
& +\int_{\Gamma_{c r}} d^{3} \vec{x}_{0} \dot{m}_{c r}\left(\vec{x}_{0}\right): G\left(\vec{x}, \vec{x}_{0}, \infty\right) \\
& \cdot \int_{V} d^{3} \vec{x}_{0} \dot{m}_{\delta \mu}\left(\vec{x}_{0}\right): G\left(\vec{x}, \vec{x}_{0}, \infty\right),
\end{aligned}
$$

where $V_{p s}(\vec{x})$ is the postseismic velocity caused by dislocation $d$ on a fault within a volume $V$ of the lithosphere that contains discrete fault surfaces. The dislocation occurs at location $\vec{x}_{0}$ at time $t=0$ on the $n$th fault $\Gamma_{n}$ and is related to the surface displacement through the moment release rate function $\dot{m}\left(x_{0}\right)$, which depends on fault geometry and slip, and the response function $G\left(\overrightarrow{\mathrm{x}}, \vec{x}_{0}, t\right)$. The five terms on the right-hand side of the equations represent the contributing factors: (1) viscoelastic relaxation from known past earthquakes (e.g., as in Table 2) with a moment release function $m$ $\left(\vec{x}_{0}\right)$ and the response function calculated for time since last earthquake at $\left(t-t_{n}\right)$ plus the recurrence interval $T_{n}$ multiplied by event index $j$ (the time derivative of the response function is used in this term and summed for all events $j$ on the $n$th fault, and the product of the moment and response functions are in turn summed over the faults in the volume $V$ ), (2) averaged interseismic velocity based on the summed moment release rate for the faults $\Gamma_{m}$ with poorly constrained slip history in volume $V$, (3) averaged interseismic velocity from the other dislocations within volume $V$ that are not associated with known faults, (4) velocity from steady creep at points on 
Table 3. GPS Data Sources

\begin{tabular}{|c|c|c|c|c|c|}
\hline Source & Network Area ${ }^{a}$ & GPS Measurement Type & Years & Number of Sites & Mean RMS (mm/a) \\
\hline Bennett et al. [2003] & WUS & campaign and permanent & through 2003 & 220 & 0.93 \\
\hline Chadwick et al. [2007] & ESRP & campaign & $1995-2004$ & 13 & 0.58 \\
\hline Chang [2004] & Wasatch front & campaign & $1992-2001$ & 39 & 0.13 \\
\hline Chang [2004] & EBR, YSRP & permanent & $1997-2005$ & 16 & 0.91 \\
\hline Gan et al. [2000] & California & campaign & 1994-1999 & 43 & 2.88 \\
\hline Hammond and Thatcher [2005] & WBR, WSRP & campaign & $1999-2003$ & 98 & 1.29 \\
\hline Hammond and Thatcher [2007] & Basin-Range & campaign & $2000-2004$ & 226 & 0.73 \\
\hline McClusky et al. [2001] & California & campaign & $1993-2000$ & 80 & 2.54 \\
\hline Payne et al. [2008] & WUS & campaign and permanent & $1994-2007$ & 273 & 0.73 \\
\hline Puskas et al. [2007b] & YSRP & campaign & $1995-2000$ & 47 & 0.73 \\
\hline Puskas et al. [2007b] & Teton fault zone & campaign & $1987-2003$ & 13 & 0.27 \\
\hline Svarc et al. [2002] & W NV & campaign & $1993-2000$ & 46 & 1.16 \\
\hline $\mathrm{PBO}$ & WUS & permanent & $1997-2008$ & 610 & 0.80 \\
\hline USGS (Flathead) & Idaho-Montana & campaign & $2001-2006$ & 15 & 1.54 \\
\hline USGS (southern Nevada) & SW Nevada & campaign and permanent & $1994-2004$ & 28 & 1.53 \\
\hline USGS (Burns) & Oregon-Idaho & campaign & 1999-2006 & 32 & 1.57 \\
\hline USGS (Kennewick) & Oregon-Washington & campaign & $2001-2005$ & 11 & 1.83 \\
\hline USGS (LaGrande) & Oregon-Idaho & campaign & $2001-2006$ & 19 & 1.78 \\
\hline USGS (Wind River) & Utah-Idaho-Wyoming & campaign & $2003-2007$ & 12 & 1.87 \\
\hline
\end{tabular}

${ }^{a}$ Abbreviations for regions EBR, eastern Basin-Range; WBR, western Basin-Range; WSRP, western Snake River Plain; ESRP, eastern Snake River Plain; YSRP, Yellowstone-eastern Snake River Plain; W NV, western Nevada; and WUS, western United States. Combined GPS type refers to both campaign and permanent station data. Mean RMS values for GPS velocity data are also included and calculated by averaging the errors for the north and east components. Number of sites refers to the number after sorting for outliers but still including sites outside the model area.

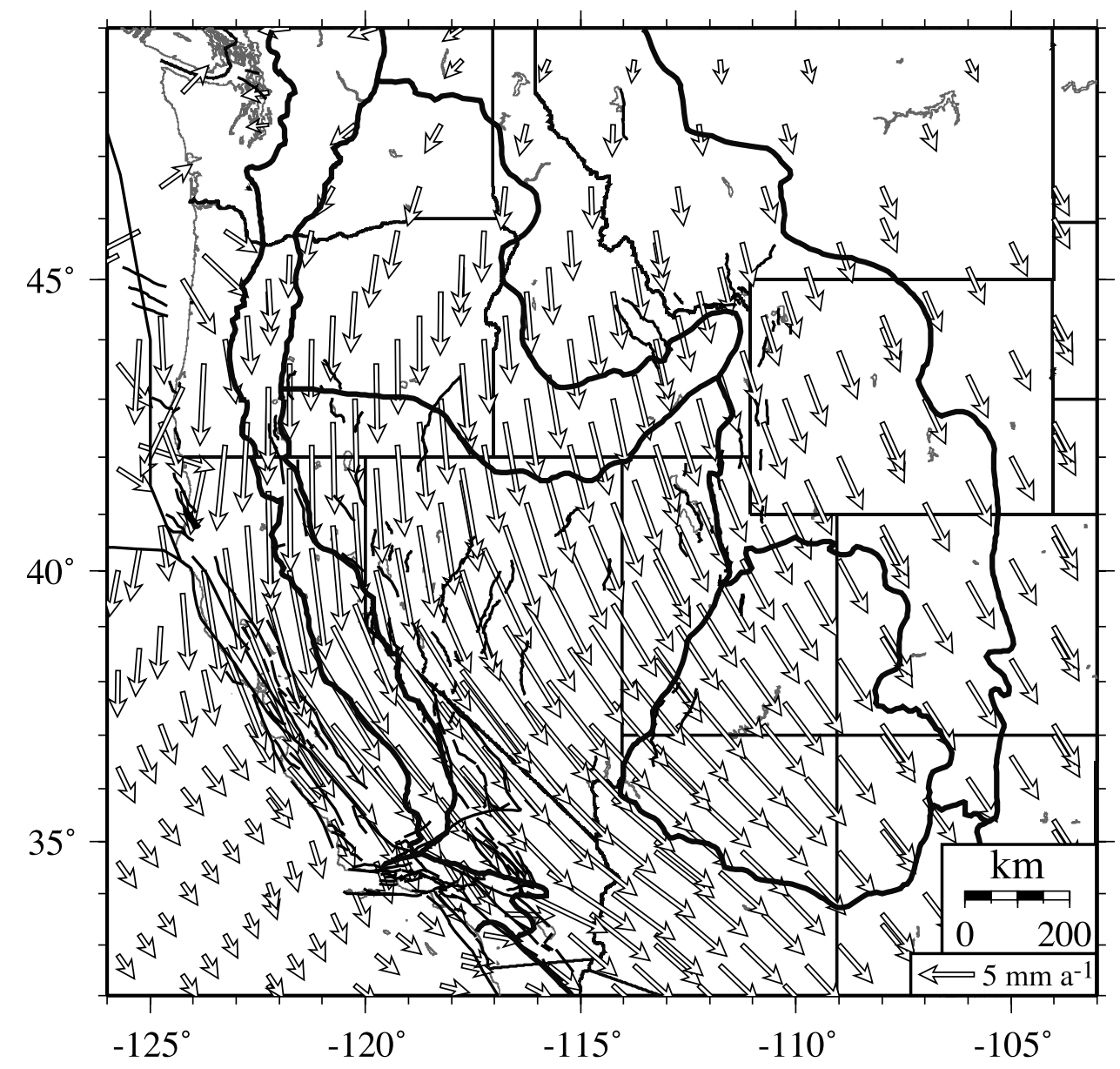

Figure 6. Postseismic deformation field arising from large earthquakes at major faults in the western United States. 
creeping fault surfaces $\Gamma_{\mathrm{cr}}$, and (5) velocity variation arising from lateral variation in the shear modulus $\delta \mu\left(\vec{x}_{0}\right)$.

[32] The resulting velocity field of the western United States is dominated by the postseismic effects of the 1700 M9.1 Cascadia subduction zone paleoearthquake, which adds up to $5 \mathrm{~mm} / \mathrm{a}$ of long-wavelength southward flow to the velocity field outside the Pacific Northwest. The two large San Andreas fault earthquakes, the 1857 M8.0 Fort Tejon and 1906 M8.0 San Francisco events, each contributed $2-4 \mathrm{~mm} / \mathrm{a}$ to the velocity field.

[33] In contrast to these large earthquakes, the contributions of the other recent, historical earthquakes are much smaller. Normal faulting earthquakes of magnitude 6.5 to 7.1 can produced flow of $\sim 1-2 \mathrm{~mm} / \mathrm{a}$ at distances of over $200 \mathrm{~km}$ away from the fault, as shown in detailed studies of the M7.5 Hebgen Lake and M7.3 Borah Peak, Idaho, earthquakes (W. L. Chang and R. B. Smith, unpublished manuscript, 2007) and the central Nevada seismic belt [Hammond et al., 2009]. The long-wavelength effects of the earthquakes caused the GPS velocities to have a strong northwest component. During modeling, the corrected GPS data were transformed into the model reference frame, with the result that the long-wavelength effects, which were relatively uniform over the model area, were mostly removed (Figure 5). We assume that effects of other large earthquakes outside the study area will be either too small to contribute to the deformation, or in the case of $M>9$ earthquakes, will have a uniform long-wavelength contribution that is eliminated by the reference frame transformation.

\subsubsection{Earthquake Slip Azimuths}

[34] Horizontal slip directions were determined from focal mechanisms of moderate to large $(M>6)$ earthquakes in the study area and were chosen to constrain motion directions at block boundaries. The magnitude cutoff of $M=$ 6 was selected as the minimum magnitude likely to produce surface displacement [Doser and Smith, 1989]. Azimuths from 15 earthquakes of $5.9<M<7.5$ were employed in the modeling (Figures 1 and 7 and Table 1).

[35] Earthquake locations, magnitudes, and focal mechanisms were primarily from the Basin-Range compilation of Doser and Smith [1989]. The historic earthquakes dated from the $1915 M 7.1\left(M_{s}=7.7\right)$ Pleasant Valley, Nevada, to the $1983 M_{s}=7.3$ Borah Peak, Idaho, events (Table 1). Doser and Smith [1989] included uncertainties for strike, dip, and rake, so it was possible to compute uncertainties for those earthquakes. These uncertainties ranged from $\pm 5^{\circ}$ to $\pm 56^{\circ}$. Fault data for the 1975 M6.1 Norris, Wyoming, earthquake were from Pitt et al. [1979] and did not include uncertainties, so an uncertainty of $\pm 18^{\circ}$ from Doser and Smith [1989] was assigned to the horizontal slip vector.

\subsubsection{Late Quaternary Fault Slip Rates}

[36] Fault slip rates were compiled from the USGS Quaternary Fault and Fold Database [Haller et al., 2002], Chang and Smith [2002], and Anderson et al. [2003]. Slip rates were chosen for Quaternary faults that coincided with block boundaries (Figure 7 and Table 4). Some of the rates from the database lacked specification of uncertainties. In these cases an arbitrary uncertainty of $\pm 20 \%$ was assumed on the basis of the upper bound errors for those slip rates with uncertainties.
[37] The fault database was also used to constrain the locations of faults and block boundaries when digitizing the block modeling. When possible, block boundaries coincided with faults whose slip rates exceeded $0.2 \mathrm{~mm} / \mathrm{a}$.

\section{Results}

[38] Tectonic blocks (Figure 3) were assumed to reflect volumes of insignificant strain, and their boundaries were determined on the basis of tectonic provinces, earthquake epicenter alignments, locations of major faults, and preliminary results from continuum modeling of deformation [Puskas et al., 2007a]. The base of the seismic layer and maximum faulting depth was implicitly assumed to be at the brittle-ductile transition depth [Smith and Bruhn, 1984] (Figure 2). The initial model had 37 blocks. During model construction, a few blocks ( 1 and 0 , and also 5 and 14) were merged owing to the absence of adequate fault or GPS data, leaving 35 blocks for the starting model. For this reason, block numbers are not consecutive when listed in figures and tables.

\subsection{Modeling Parameters and Statistics}

[39] The reduced $\chi^{2}$ statistic (equation (5)) was employed to evaluate how well the modeled deformation fit the observed data. The value of the parameter depends on the residuals, data uncertainties, number of iterations of the downhill simplex method, and data scaling. We chose to use 500 iterations for the downhill simplex, as the $\chi^{2}$ statistic did not improve greatly with more iterations (Figure $4 a$ ).

[40] Of the parameters affecting the $\chi^{2}$ statistic, the residual is assumed to have the greatest effect. The data uncertainties, or $\sigma_{\mathrm{i}}$ in equation (5), will be the same for each model, while the degrees of freedom vary from 2391 to 2479 . The total $\chi^{2}$ value ranged from 13,179 to 23,133 . If the total $\chi^{2}$ value is plotted as a function of the degrees of freedom (Figure 4b), we see that there is no trend and conclude that the degrees of freedom do not have a significant effect on the reduced $\chi^{2}$ statistic. Furthermore, the reduced $\chi^{2}$ statistic is assumed to be a good indicator of the quality of fit.

[41] Models were compared using an $F$ test [e.g., Wallace et al., 2004] to evaluate the null hypothesis that the residuals from two runs have the same variance. The $F$ test calculates the ratio of variances between two sets of residuals and the probability of the null hypothesis [Press et al., 1992]. If the null hypothesis was true, then the two models being compared have the same variance and fit the data equally well. We consider the probability of having different variances above $90 \%$ to be statistically significant.

[42] Two simple models were constructed for use as a basis of comparison with later ones. The free-slip $(\Phi=0)$ model is the simplest, solving for block motions while allowing free slip on unlocked faults and assuming rigid blocks (no strain). An unlocked fault will have no elastic loading, so only the block rotation and strain rate terms from equation (4) will contribute to the velocity. The second model is the fault slip model (also called the fault model), with locked faults $(\Phi=1)$ in the upper crust. The upper crust or locked layer was set to $15 \mathrm{~km}$ depth. Fault slip rates (Table 4) were used as constraints for the dislocations in the fault model. 


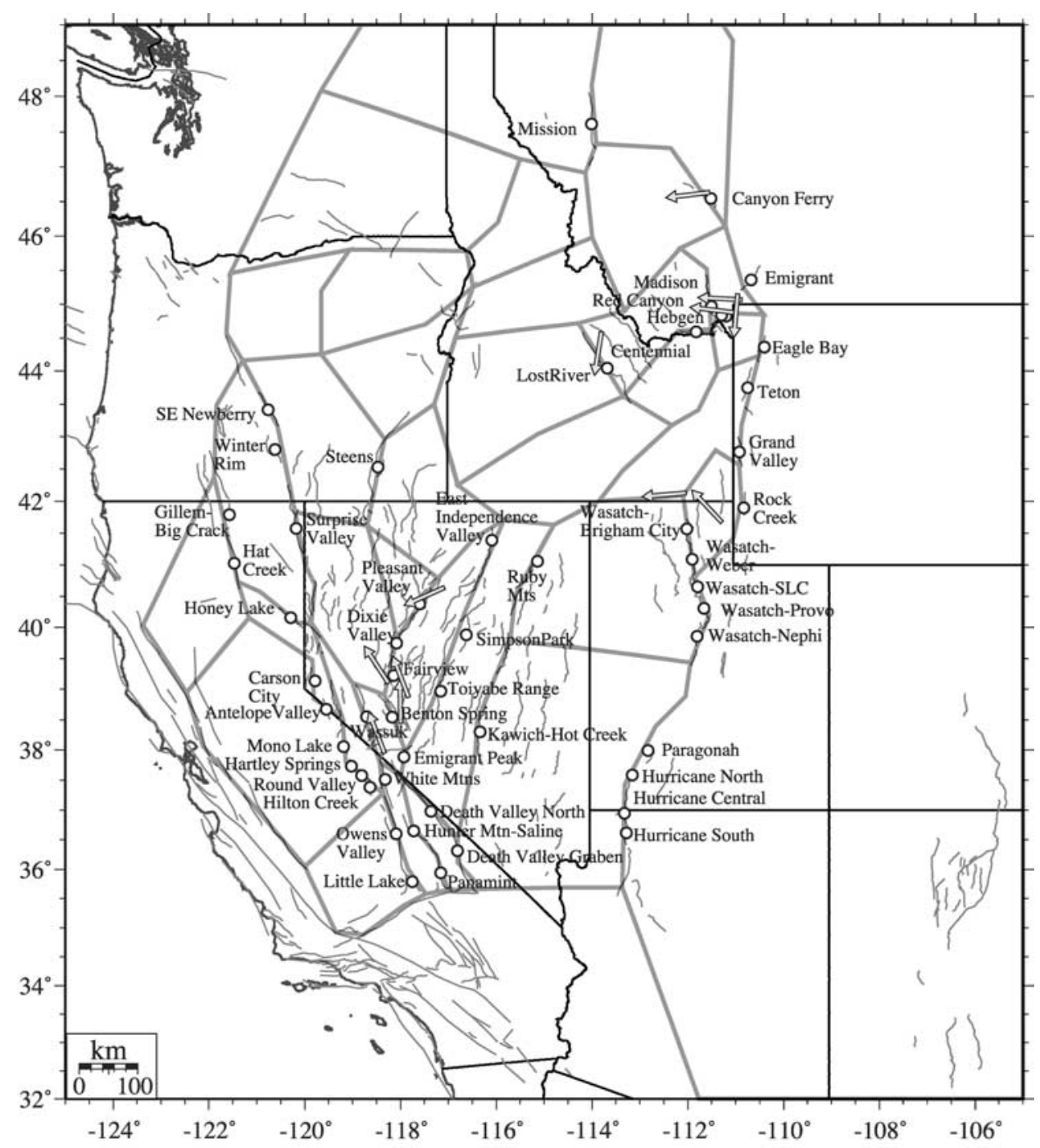

Figure 7. Late Quaternary geologic fault-slip rate locations (white circles) and fault-slip azimuths from focal mechanisms (arrows). Faults associated with fault-slip rates are listed in Table 4. Block boundaries are shown as heavy, gray lines.

[43] The free-slip model had a $\chi^{2}$ value of 6.81 and the fault slip model had a value of 6.46. Subsequent model runs tested the effects of grouping blocks to share a single pole of rotation and the effects of including strain within blocks. Each of these models was run twice: once without locked faults for comparison to the free-slip model and once with locked faults for comparison to the fault model.

[44] By varying the block groupings and strain distribution, we sought to minimize the difference between observed and calculated velocities (equation (5)). The final, most improved model had a $\chi^{2}$ value of 5.46 , with $15 \%$ better fit than the initial free-slip $\chi^{2}$ value of 6.46.

\subsection{Modeled Fault Slip Rates}

[45] Although we considered the possibility of locking at all the boundary faults, this assumption proved to be problematic. The availability of fault slip rate data and distribution of GPS site velocities varied within the study area (Figures 5 and 7), such that not all segments of all block boundaries had the same density of information.
Moreover, the close $\sim 25 \mathrm{~km}$ spacing of Basin-Range faults is comparable to the 5 to $50 \mathrm{~km}$ baselines between GPS stations. If two or more adjacent faults are being loaded, then the contributions of individual faults cannot be resolved by the GPS measurements because of horizontal aliasing. In parts of the Columbia Plateau, Snake River Plain, and northern Rocky Mountains, there are no mapped faults or earthquakes to distinguish block boundaries, thus the blocks were based on changes in the magnitude and direction of GPS velocities, and free rotation was prescribed for the boundaries.

[46] The magnitude of the surface deformation of a fault with a locked upper layer and creeping lower layer depends strongly on fault slip rate, fault geometry, and distance from fault. In Figure 2, fault slips are parameterized as dislocations on the creeping lower layer. For normal or strike-slip faults with $2 \mathrm{~mm} / \mathrm{a}$ slip or less, maximum surface motion will be approximately $0.2 \mathrm{~mm} / \mathrm{a}$ at distances up to $30 \mathrm{~km}$ on either side of the fault. Thus the effects of fault loading in much of the western U.S. interior, where fault slip rates are 
Table 4. Fault and Associated Slip Rates From the USGS Quaternary Fault and Fold Database ${ }^{\mathrm{a}}$

\begin{tabular}{|c|c|c|}
\hline Fault & $\begin{array}{l}\text { Slip Rate } \\
\text { (mm/a) }\end{array}$ & $\begin{array}{l}\text { Error } \\
( \pm 1 \sigma) \\
\end{array}$ \\
\hline Wasatch-Brigham City segment, Utah & 0.9 & 0.4 \\
\hline Wasatch-Weber segment, Utah & 1.6 & 0.9 \\
\hline Wasatch-Salt Lake City segment, Utah & 1.2 & 0.7 \\
\hline Wasatch-Provo segment, Utah & 1.2 & 0.1 \\
\hline Wasatch-Nephi segment, Utah & 1.7 & 1.3 \\
\hline Hurricane-Central segment, Utah & 0.2 & 0.04 \\
\hline Hurricane-North segment, Utah & 0.2 & 0.04 \\
\hline Hurricane-South segment, Utah & 0.08 & 0.02 \\
\hline Paragonah, Utah & 0.46 & 0.09 \\
\hline Eagle Bay, Wyoming & 0.48 & 0.1 \\
\hline Teton, Wyoming & 1.3 & 0.26 \\
\hline Grand Valley, Wyoming & 1.1 & 0.22 \\
\hline Rock Creek, Wyoming & 1.7 & 0.34 \\
\hline Lost River, Idaho & 0.15 & 0.03 \\
\hline Canyon Ferry, Montana & 0,13 & 0.03 \\
\hline Centennial, Montana & 0.9 & 0.18 \\
\hline Emigrant, Montana & 0.25 & 0.05 \\
\hline Madison, Montana & 0.4 & 0.08 \\
\hline Mission, Montana & 0.32 & 0.06 \\
\hline Hebgen Lake, Montana & 0.5 & 0.1 \\
\hline Red Canyon, Montana & 0.5 & 0.1 \\
\hline Antelope Valley, Nevada & 0.8 & 0.2 \\
\hline Benton Springs, Nevada & 0.26 & 0.05 \\
\hline Carson City, Nevada & 0.1 & 0.02 \\
\hline Dixie Valley, Nevada & 0.3 & 0.06 \\
\hline Eastern Independence Valley, Nevada & 0.1 & 0.02 \\
\hline Emigrant Peak, Nevada & 0.76 & 0.15 \\
\hline Fairview Peak, Nevada & 0.1 & 0.02 \\
\hline Kawich-Hot Creek, Nevada & 0.2 & 0.04 \\
\hline Pleasant Valley, Nevada & 0.1 & 0.02 \\
\hline Ruby Mountains, Nevada & 0.28 & 0.06 \\
\hline Simpson Park, Nevada & 0.22 & 0.04 \\
\hline Toiyabe Range, Nevada & 0.22 & 0.04 \\
\hline Wassuk, Nevada & 0.55 & 0.11 \\
\hline Death Valley North, California & 5 & 1 \\
\hline Death Valley Graben, California & 4 & 0.8 \\
\hline Gillem-Big Crack, California & 1 & 0.2 \\
\hline Hartley Springs, California & 0.5 & 0.1 \\
\hline Hat Creek, California & 1.5 & 0.3 \\
\hline Hilton Creek, California & 2.5 & 0.5 \\
\hline Honey Lake, California & 2.5 & 0.5 \\
\hline Hunter Mountain-Saline Valley, California & 2.5 & 0.5 \\
\hline Little Lake, California & 0.7 & 0.14 \\
\hline Mono Lake, California & 2.5 & 0.5 \\
\hline Owens Valley, California & 1.5 & 0.3 \\
\hline Panamint, California & 2.5 & 0.5 \\
\hline Round Valley, California & 1.0 & 0.2 \\
\hline Surprise Valley, California & 1.3 & 0.3 \\
\hline White Mountains, California & 1 & 0.2 \\
\hline Steens, Oregon & 0.3 & 0.06 \\
\hline SE Newberry fault zone, Oregon & 0.5 & 0.1 \\
\hline Winter Rim, Oregon & 0.43 & 0.09 \\
\hline
\end{tabular}

\footnotetext{
${ }^{\mathrm{a}}$ See Haller et al. [2002], Chang and Smith [2002], and Anderson et al.
} [2003].

typically 0.2 to $2 \mathrm{~mm} / \mathrm{a}$, are generally less than the mean RMS of the GPS data (Table 3) and fault locking is not necessarily required.

[47] In our fault models, locked faults were prescribed for boundaries coincident with a known fault or groups of multiple faults (Table 4). These structures were modeled as a combination of normal, oblique, and strike-slip faults locked above a $15 \mathrm{~km}$ depth. The resulting model improved the $\chi^{2}$ value to 6.46 compared to the free-slip value of 6.81 . Because the block boundary faults are simplifications of fault zones, boundary slip rates are expected to exceed slip rates for actual faults whose locations coincide with the block boundary. The $F$ test comparing the free slip with the fault model had an $F$ value of 1.09 with a $97 \%$ probability of having different variances. All subsequent discussions of modeling results assume that the models contain locked faults and are being compared to the original fault model.

\subsection{Poles of Rotation and Block Grouping}

[48] Errors in pole-of-rotation locations (Table 5) made it difficult to assess whether any of the blocks shared poles. Therefore we compared block velocities in preference to their poles to determine whether they should be grouped together. We evaluated several combinations of grouped blocks and focused on testing blocks north of the eastern Snake River Plain, where normal faulting reaches its northernmost limit [Stickney and Bartholemew, 1987] and in the Basin-Range. To confirm that block groupings are valid when other blocks had their motions changed, additional test runs were made that combined block groupings and strain in blocks.

[49] Grouping blocks 2, 3, and 12 in the northern Rocky Mountains (Figure 3) increased the $\chi^{2}$ value: 6.49 for the grouped run versus 6.46 for the ungrouped fault run. The $F$ test calculations returned a $0 \%$ probability that the grouped run had a different variance. On the basis of these results, having these three blocks share the same pole of rotation is not required but will not strongly affect the modeling.

[50] Grouping blocks 2, 3, 12, and 13 (ESRP plus northern Rocky Mountains) increased the $\chi^{2}$ value, suggesting that there is sufficient differential motion between the blocks to the north and the ESRP to leave them as separate blocks. This result is not immediately apparent from earlier GPS surveys [Puskas et al., 2007b; Chadwick et al., 2007] or geologic studies [e.g., Rodgers et al., 1990], and the sum of the slip rates on large faults adjacent to the plain is similar to the rate of southwest motion of the plain. However, grouping the eastern Snake River Plain with the block to the south (blocks 13 and 5) produced an improvement of the $\chi^{2}$ value from 6.46 to 5.97 , with a $98 \%$ probability of different variances according to the $F$ test.

[51] The initial microplate configuration (Figure 3) had divided the eastern Snake River Plain into two subblocks (blocks 13 and 19), with the division at the approximate location of the Great Rift [Kuntz et al., 1982]. Unifying the subblocks into a single block increased the $\chi^{2}$ parameter to 6.49 , but with only $87 \%$ probability of having a different variance. The ESRP is generally considered to be a single, rigid block [e.g., Anders et al., 1989; Smith and Braile, 1994]. Our results indicate that this is not necessarily the case, and that whether or not the ESRP is divided into two blocks does not make a statistically significant difference to the final outcome.

[52] The eastern Basin-Range was divided into northern and southern subblocks, with the division between the southern end of the Wasatch fault zone, Utah, and the northern end of the Hurricane fault zone, southern Utah (Figure 3). The subblocks were found to have different velocities and directions. The difference in $\chi^{2}$ value between the grouped and ungrouped runs was 6.87 versus 6.46. Despite the difference in the $\chi^{2}$ value, the $F$ test predicted only a $3 \%$ probability of the grouped model having a better fit than the fault model. Because the 
Table 5. Modeled Block Velocities and Poles of Rotation for the Best Fit Model ${ }^{\mathrm{a}}$

\begin{tabular}{|c|c|c|c|c|c|c|c|c|c|c|c|}
\hline Block & $\begin{array}{l}\text { Velocity } \\
(\mathrm{mm} / \mathrm{a})\end{array}$ & $\begin{array}{l}\text { Velocity } \\
\text { RMS } \\
(\mathrm{mm} / \mathrm{a})\end{array}$ & $\begin{array}{r}\text { Velocity } \\
\text { Azimuth }\end{array}$ & $\begin{array}{l}\text { Azimuth } \\
\text { Error }\end{array}$ & $\begin{array}{c}\text { Pole } \\
\text { Longitude }\end{array}$ & $\begin{array}{c}\text { Pole } \\
\text { Latitude }\end{array}$ & $\begin{array}{c}\text { Omega } \\
(\mathrm{deg} / \mathrm{Ma})\end{array}$ & $\begin{array}{l}\text { Omega } \\
\text { Error }\end{array}$ & Max & Min & $\begin{array}{l}\text { Rotation of } \\
\text { Error Ellipse }\end{array}$ \\
\hline 2 & 0.78 & 0.08 & 50 & 5 & -111.4 & 45 & -0.24 & 0.00 & 0.3 & 0.1 & 176 \\
\hline 3 & 0.1 & 0.1 & 89.00 & 0.01 & -111.4 & 45 & -0.24 & 0.00 & 0.3 & 0.1 & 176 \\
\hline 4 & 0.9 & 0.1 & -134 & 7 & -111.8 & 45 & -0.53 & 0.07 & 0.2 & 0.1 & 128 \\
\hline 5 & 0.9 & 0.1 & -96 & 1 & -112.8 & 50 & -0.07 & 0.03 & 3.6 & 0.7 & 177 \\
\hline 6 & 1.1 & 0.1 & -33 & 9 & -113.0 & 41 & 0.4 & 0.1 & 0.5 & 0.3 & 58 \\
\hline 7 & 3.0 & 0.1 & -68 & 1 & -105.3 & 53 & -0.12 & 0.03 & 4.5 & 0.4 & 205 \\
\hline 8 & 4.6 & 0.1 & -78.00 & 0.09 & -112.4 & 45 & -0.30 & 0.01 & 0.5 & 0.1 & 185 \\
\hline 9 & 3.8 & 0.2 & 102.0 & 0.7 & -112.1 & 57 & 0.22 & 0.05 & 3.2 & 0.2 & 9 \\
\hline 10 & 3.6 & 0.5 & 97.0 & 2.1 & -115.7 & 45 & -1.2 & 0.4 & 0.7 & 0.2 & 174 \\
\hline 11 & 2.0 & 0.3 & 78.0 & 3.3 & -114.7 & 44 & -1.2 & 0.2 & 0.3 & 0.2 & 171 \\
\hline 12 & 0.41 & 0.02 & -14.0 & 6.3 & -111.4 & 45 & -0.24 & 0.00 & 0.3 & 0.1 & 176 \\
\hline 13 & 0.8 & 0.1 & -97.0 & 1.7 & -112.8 & 50 & -0.07 & 0.03 & 3.6 & 0.7 & 177 \\
\hline 15 & 4.0 & 0.1 & 102.0 & 0.6 & -110.6 & 62 & 0.13 & 0.04 & 7.0 & 0.6 & 22 \\
\hline 16 & 3.6 & 0.1 & 69 & 2 & -115.2 & 39 & -0.28 & 0.06 & 2.0 & 0.3 & 148 \\
\hline 17 & 2.6 & 0.3 & 6 & 1 & -128.6 & 44 & 0.2 & 0.2 & 13.6 & 1.3 & 272 \\
\hline 18 & 1.4 & 0.1 & -17 & 2 & -110.0 & 45 & -0.17 & 0.08 & 2.5 & 0.5 & 258 \\
\hline 19 & 1.0 & 0.1 & -78 & 2 & -112.8 & 50 & -0.07 & 0.03 & 3.6 & 0.7 & 177 \\
\hline 20 & 4.8 & 0.1 & -58 & 1 & -102.7 & 52 & -0.16 & 0.05 & 7.4 & 0.4 & 221 \\
\hline 21 & 3.9 & 0.1 & 55 & 1 & -115.2 & 39 & -0.28 & 0.06 & 2.0 & 0.3 & 148 \\
\hline 22 & 4.9 & 0.1 & 5.0 & 0.2 & -108.9 & 42 & -0.31 & 0.04 & 1.6 & 0.3 & 101 \\
\hline 23 & 3.6 & 0.2 & -9 & 1 & -107.5 & 43 & -0.25 & 0.09 & 3.9 & 0.4 & 268 \\
\hline 24 & 4.3 & 0.6 & -20 & 7 & -93.2 & 45 & -0.1 & 0.1 & 24.0 & 4.4 & 90 \\
\hline 25 & 5.2 & 0.1 & -43 & 1 & -93.7 & 52 & -0.14 & 0.07 & 14.8 & 0.5 & 243 \\
\hline 26 & 6.2 & 0.1 & -10.0 & 0.3 & -104.6 & 43 & -0.27 & 0.04 & 2.2 & 0.3 & 91 \\
\hline 27 & 6.2 & 0.1 & -31.0 & 0.8 & -103.7 & 46 & -0.26 & 0.04 & 2.9 & 0.3 & 248 \\
\hline 28 & 7.8 & 0.2 & -44 & 1 & -173.9 & -31 & 0.07 & 0.01 & 76.4 & 1.3 & 40 \\
\hline 29 & 11.8 & 0.2 & -42 & 1 & -97.2 & 48 & -0.3 & 0.2 & 13.2 & 0.4 & 240 \\
\hline 30 & 8.0 & 0.3 & -50 & 2 & -125.7 & 27 & 0.3 & 0.4 & 20.3 & 0.6 & 35 \\
\hline 31 & 11.1 & 0.2 & -40 & 1 & -157.9 & -1 & 0.1 & 0.1 & 66.2 & 1.1 & 36 \\
\hline 32 & 11.3 & 0.2 & -45.0 & 0.8 & -101.5 & 49 & -0.36 & 0.09 & 5.7 & 0.3 & 237 \\
\hline 33 & 10.5 & 0.2 & -28 & 1 & -115.7 & 43 & -1.0 & 0.1 & 1.0 & 0.2 & 246 \\
\hline 34 & 15.8 & 0.1 & -48.0 & 0.4 & -109.1 & 47 & -0.70 & 0.02 & 0.6 & 0.1 & 230 \\
\hline 35 & 16.1 & 0.1 & -47.0 & 0.4 & -99.6 & 48 & -0.45 & 0.06 & 3.4 & 0.1 & 235 \\
\hline
\end{tabular}

${ }^{a}$ Omega refers to the rotation rate in deg/Ma. Pole position errors give the semimajor (Max) and semiminor (Min) axes of the error ellipse and the rotation of the error ellipse.

grouping of the eastern Basin-Range subblocks does not strongly affect the fit, we made additional test runs with grouped and ungrouped subblocks before assembling the final model.

[53] Several block combinations were evaluated for the western Basin-Range. Grouping this region's blocks together (while excluding the southern part of the Walker Lane seismic belt) led to a higher $\chi^{2}$ value of 6.78 , but with a probability of only $60 \%$ for different variance. Attempting to combine the small block 24 in northwest Nevada with one of the adjacent blocks did not improve the $\chi^{2}$ value, but again the $F$ tests showed that none of these models had significantly different variances. The results for these test runs suggest that the western Basin-Range is better modeled by many small blocks rather than a few large blocks.

[54] Additionally, we tested grouping of the Sierra Nevada subblocks (blocks 33-35) and found that a better model solution was obtained when the three subblocks were allowed to move independently. The difference in $\chi^{2}$ was 7.20 for the grouped model compared with the control run of 6.46 for the ungrouped model. This is contrary to reports from prior studies that found that Sierra Nevada was a rigid block [e.g., Dixon et al., 2000]. However, Dixon et al. [2000] used GPS velocities from the interior of the Sierra Nevada block to calculate uniform motion and found highvelocity gradients at the block boundaries that were associated with large, active faults. Inaccuracies in the postseismic viscoelastic corrections may also contribute. Data from GPS stations in the boundary zones can plausibly lead to our model solution that fits different velocities to different parts of the Sierra Nevada. A more likely scenario is that a decrease in velocities in northern California (block 33) does not fit with the rest of the Sierra Nevada blocks and skews the results. An examination of the modeled block velocities reveals that the two southern blocks (34 and 35) have approximately the same velocity (difference less than $1 \mathrm{~mm} / \mathrm{a}$ ) and same direction, while the northern block 32 is about $5 \mathrm{~mm} / \mathrm{a}$ slower and has a more northerly direction. The division of the Sierra Nevada may therefore reflect problems with the northern boundary, as this is a region where GPS velocities change rapidly in direction and magnitude.

[55] A few models tested grouping of blocks in the Columbia Plateau. We found that grouping blocks in northeast Oregon (Figure 3) did not improve the $\chi^{2}$ value, although only grouping blocks 16 and 17 (eastern Oregon) had statistical significance above the threshold of $90 \%$.

\subsection{Strain Within Blocks}

[56] The microplate model assumes rigid block motion with elastic strain concentrated at boundaries, but distributed deformation can be incorporated by allowing strain within blocks. Distributed deformation may arise from a combination of unmodeled faulting, volcanic deformation, or vis- 
Table 6. Principal Strain Rates and Strain Rate Errors

\begin{tabular}{|c|c|c|c|c|c|c|}
\hline Block & $\begin{array}{c}\text { Minimum } \\
\text { Principal } \\
\text { Strain Rate } \\
\end{array}$ & $\begin{array}{l}\text { Minimum } \\
\text { Rate Error }\end{array}$ & $\begin{array}{l}\text { Maximum } \\
\text { Principal } \\
\text { Strain Rate }\end{array}$ & $\begin{array}{l}\text { Maximum } \\
\text { Rate Error }\end{array}$ & $\begin{array}{c}\text { Azimuth of Minimum } \\
\text { Strain Rate }\end{array}$ & $\begin{array}{l}\text { Azimuth } \\
\text { Error }\end{array}$ \\
\hline 7 & -10.2 & 0.8 & 6.5 & 0.6 & 1 & 2 \\
\hline 13 & -10 & 2 & -5 & 2 & -45 & 20 \\
\hline 20 & -2.2 & 0.7 & 58 & 4 & 17 & 1 \\
\hline 25 & -3.7 & 0.7 & 45 & 4 & 12 & 2 \\
\hline
\end{tabular}

cous deformation. Blocks likely to contain internal strain include the Basin-Range microplates, where there is a high density of faults, and the YSRP and northern Rocky Mountain microplates, where low deformation rates and sparse data mean that block boundaries are uncertain.

[57] Adding strain to the blocks north of the ESRP had mixed results with respect to the $\chi^{2}$ value, with statistically significant improvements only in the cases where block 2 or block 10 were allowed to strain. An examination of the distribution of GPS velocities (Figure 5) shows only three vectors within block 2, while block 10 has all vectors located at the western boundary of the block. While three data points in block 2 are enough to constrain a horizontal strain tensor, they are not enough to assess scatter in the velocity vectors. Likewise, the uneven data distribution in block 10 makes it impossible to determine whether there is uniform strain within this block. Because the strain rates within these blocks could not be adequately constrained, the simpler model of no strain in the northern blocks was used in later analysis.

[58] The $\chi^{2}$ value decreased when strain was allowed in blocks 22 and 24 of the western Basin-Range, though only block 24 had statistical significance above $90 \%$. The presence of strain in block 24 can be attributed to the presence of only two GPS velocity vectors within the block, so any strain rates would be poorly constrained.

\subsection{Deformation Model}

[59] Additional models were constructed by incorporating both block groupings and strain rates from sections 4.3 and 4.4 into a single model. We examined over 100 combinations of groupings and strains. These combinations examined groupings of multiple blocks: for example, blocks 13 and 19 might be grouped into one block, while blocks 16 and 21 may be grouped into another block. Two or three adjacent blocks might be assigned the same pole of rotation, and combinations of groupings in the YSRP region, BasinRange, and Pacific Northwest were explored. The grouped models were in turn combined with various combinations of straining blocks. The initial test run included all modifications that improved the $\chi^{2}$ parameter and had a greater than $90 \%$ probability of difference, but later test runs explored different permutations.

[60] Ultimately the model with the greatest improvement was one of the many permutations that we tested. Interactions between blocks and groups of blocks meant that making multiple changes to the initial fault model did not cumulatively improve the $\chi^{2}$ value.

[61] The best results were obtained when grouping blocks in the northern Rocky Mountains (blocks 2, 3, 12), blocks in the Snake River Plain and south arm of the tectonic parabola (blocks 5, 13, 19), and blocks in northeast Oregon (blocks 16, 21). Additionally, strain was required in the eastern
Snake River Plain (block 13), the eastern Basin-Range (block 7), and parts of the western Basin-Range (blocks 20 and 25). The $\chi^{2}$ value was 5.46. The final block velocities are listed in Table 5 and the final strain rates are listed in Table 6. The results are illustrated in Figure 8. One other model configuration had the same $\chi^{2}$ value that used the same set of block groupings plus strain in most of the western Basin-Range blocks. We prefer the first model, as it requires strain in fewer blocks and therefore has a simpler geometry.

[62] In the final model, the blocks in the northern Rocky Mountains moved northeastward at $0.78 \pm 0.08 \mathrm{~mm} / \mathrm{a}$. Because of the uneven and sparse distribution of GPS data, we did not attempt to estimate strain for these blocks. The eastern Snake River Plain itself moved west at a velocity of $0.8 \pm 0.1 \mathrm{~mm} / \mathrm{a}$, so the differential motion of $\sim 1 \mathrm{~mm} / \mathrm{a}$ was not large. The two subblocks comprising the eastern Snake River Plain were constrained to have the same pole of rotation, along with the south arm of the tectonic parabola, so motion was uniform for these three blocks, with no differential motion to account for.

[63] The easternmost part of the ESRP (block 13) was affected by the high southwest velocity of the Yellowstone Plateau (block 4) at $0.9 \pm 0.1 \mathrm{~mm} / \mathrm{a}$ that is apparently "pushing" the Snake River Plain and introducing contraction rates of $10 \pm 2 \mathrm{n} \varepsilon / \mathrm{a}$ to the northwest and $5 \pm 2 \mathrm{n} \varepsilon / \mathrm{a}$ to the southwest in the ESRP (block 13). The motion of the ESRP is likely also affected by the potential gradient of high topography, which is "pulling" the ESRP downhill.

[64] Elsewhere, model velocities generally increase from north to south: $0.78 \pm 0.08 \mathrm{~mm} / \mathrm{a}$ in block 2 in western Montana versus $4.6 \pm 0.1 \mathrm{~mm} / \mathrm{a}$ in block 8 in southern Utah. Velocities also increase from east to west: $4.6 \pm 0.1 \mathrm{~mm} / \mathrm{a}$ in block 8 in Utah versus $16.1 \pm 0.1 \mathrm{~mm} / \mathrm{a}$ in the Sierra Nevada.

[65] We evaluated the above results by constructing velocity profiles across various provinces in the western interior (Figure 9). Velocities for GPS sites were calculated perpendicular and parallel to the profile. The distance of the GPS velocity points from the lines of modeled velocity represents the scatter of the models.

[66] In the Yellowstone-Snake River Plain (profile A), there was scatter of up to $3 \mathrm{~mm} / \mathrm{a}$ in the profile-parallel component of motion and $5 \mathrm{~mm} / \mathrm{a}$ in profile-normal motion. The profile-normal velocities are particularly underestimated in the Yellowstone Plateau block (block 4). This is due to variations in rate of southwest motion, and the scatter may be caused by volcanic deformation that was not adequately removed from the original GPS data set.

[67] Profile B crossed the Basin-Range from northern Utah to northern Nevada. There is considerable residual scatter at the boundary between the Basin-Range and stable North America (blocks 7 and 0) that corresponds to the 


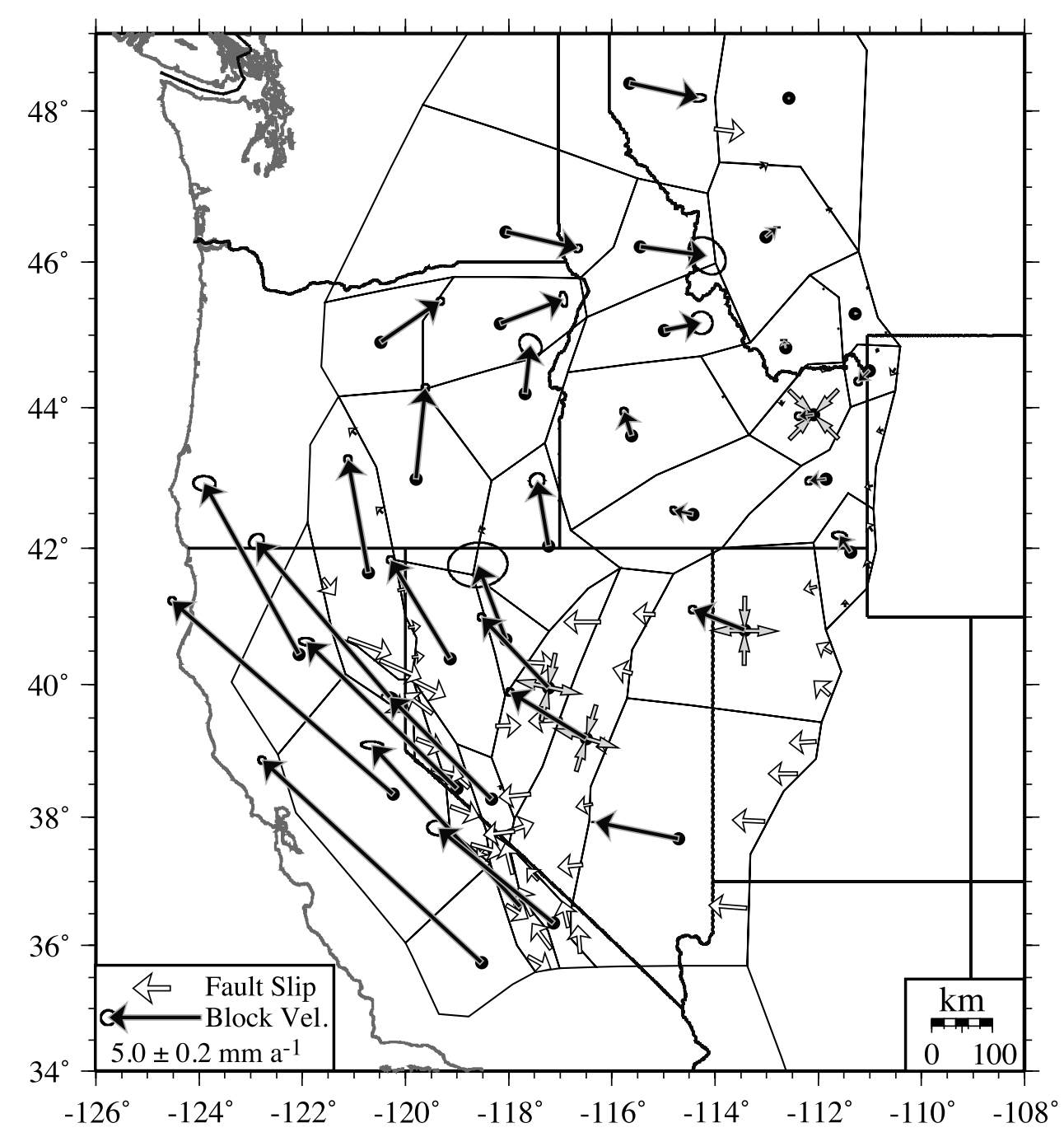

Figure 8. Modeled block velocities (black arrows), strain rates (gray crosses), and fault slip rates (white arrows) for the western U.S. interior. Best fit model from section 4.5 is shown. Error ellipses for block velocities are $2 \sigma$. Large gray arrows represent orientation of principal strain rates and are not to scale. Calculated strain rates are listed in Table 6. Slip vectors represent relative motions between blocks.

Wasatch Front. Most of the scatter along the Wasatch Front is $3 \mathrm{~mm} / \mathrm{a}$ or less. For most of this profile, scatter is on the order of $2 \mathrm{~mm} / \mathrm{a}$ or less, indicating a good fit for modeled velocities. In block 24, the model tends to overestimate the profile-normal component by $1-2 \mathrm{~mm} / \mathrm{a}$, meaning that the model predicts more northward motion than observed in the data. Scatter in the profile-parallel component is less than $1 \mathrm{~mm} / \mathrm{a}$, so the westward component of motion fits the observed data reasonably well. In block 20, the model underestimates the northward motion by $1-2 \mathrm{~mm} / \mathrm{a}$ while predicting a change of $2 \mathrm{~mm} / \mathrm{a}$ in the westward component that is not observed in the data.

[68] Profile C crossed the Basin-Range in central Utah and Nevada, and the model matches the observed data until block 20 . In both block 20 and block 25 , the model predicts increases of 3 to $4 \mathrm{~mm} / \mathrm{a}$ in the profile-parallel motion (i.e., westward motion) that is not observed in the data. The large increase in modeled westward motion is due at least partly to strain in these two blocks. However, the profile-normal component of profile $\mathrm{C}$ has a very good fit, with scatter of
$1 \mathrm{~mm} / \mathrm{a}$ or less for most of the profile. Other model parameter combinations that do not require strain in blocks 20 and 25 were tried, but the overall fit to the data was poorer, resulting in higher $\chi^{2}$ values.

[69] Profile D in north central Nevada and southern Oregon matches the data with a scatter of $2 \mathrm{~mm} / \mathrm{a}$ or less. Profile E predicts the decrease in profile-parallel velocity from south to north, with scatter of 2 to $3 \mathrm{~mm} / \mathrm{a}$ in northward motion. This profile also predicts a decrease in the rate of westward motion and concomitant increase in eastward motion in the profile-normal component from south to north. The model underestimates the rate of decrease in velocity of block 26 in the westward (profilenormal) and northward (profile-parallel) motions.

[70] As another check on the results, we constructed a map showing the observed and modeled velocities in the Yellowstone region (Figure 10). The blocks to the north of the Yellowstone-Snake River Plain province have significant scatter in the observed GPS data. The center of regional rotation is located at block 12 north of the ESRP, but the 

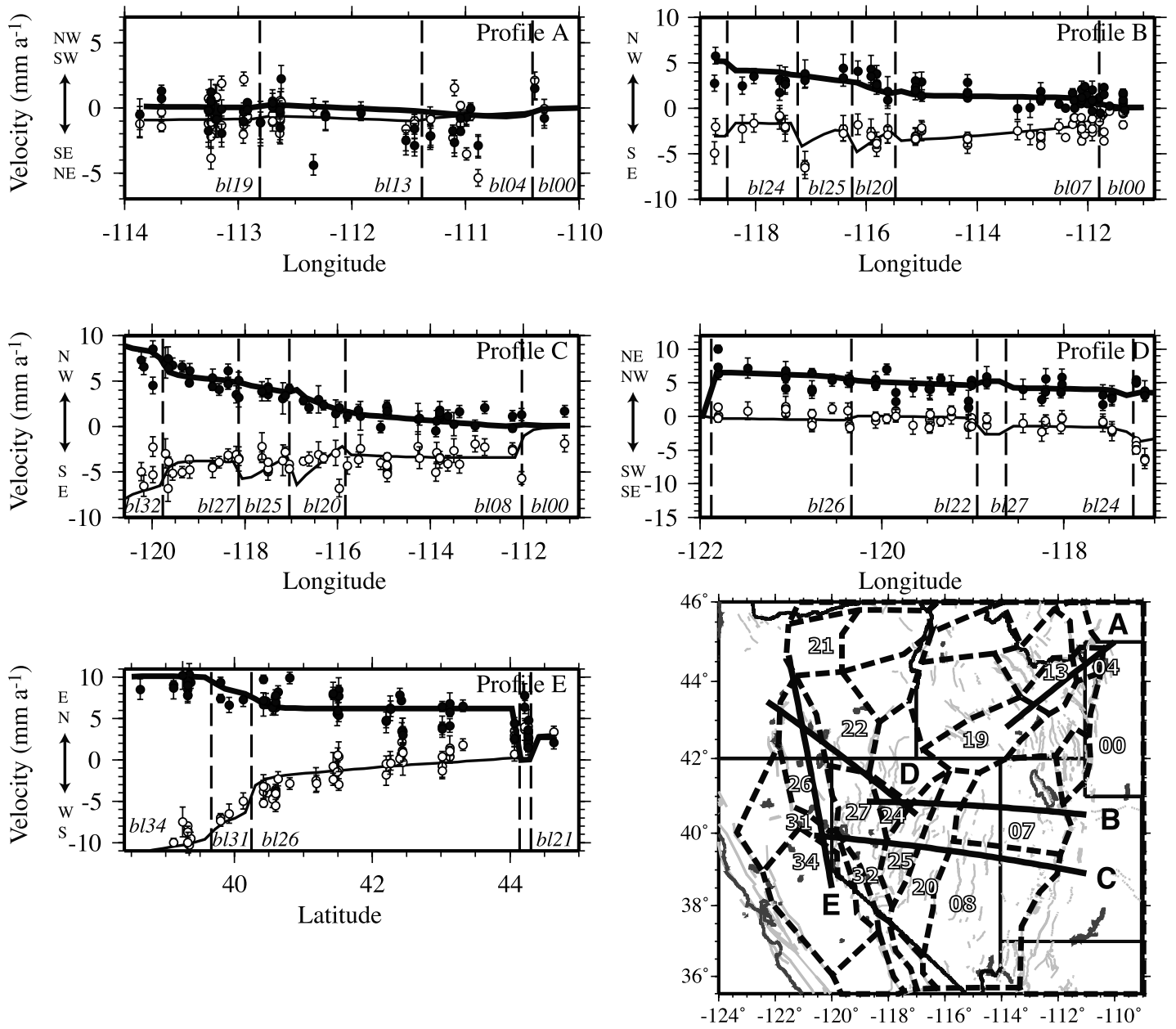

Figure 9. Profiles and index map showing observed velocities from GPS and modeled velocities for the final deformation model. Velocities were calculated parallel and normal to profiles. White circles represent observed data parallel to the profile and are modeled by the thin black line. Black circles represent velocity data perpendicular to the profile and are modeled by the thick black line. Block boundaries are marked with heavy dashed lines and are numbered in the indexed map.

modeled velocities tend to underestimate the observed data. The model predicts westerly motion in the eastern Snake River Plain (block 13), though the observed data, except for some outliers, tend to have more southwest motion. Northwest motion across the Wasatch Fault at the boundary between block 0 and block 7 contrasts with westward motion in northern Utah and southwest motion in southern Idaho and appears to be the source of north-south contraction in the northeastern Basin-Range.

[71] For a third check, plots of velocity magnitude versus direction were constructed for all the models, with the final, best fit model highlighted along with the free-slip model and the fault model. Velocity plots for selected blocks are shown in Figure 11. Such plots illustrate how much block motions vary depending on plot parameters used and the availability of GPS data (Figure 5). For example, block 2 in western Montana has few GPS data to constrain motion and those GPS velocities are $1 \mathrm{~mm} / \mathrm{a}$ or less. Consequently, most models predict a block velocity of $2 \mathrm{~mm} / \mathrm{a}$ or less, but the direction of motion can be either eastward or westward depending on model constraints. The best fit model predicts northeastward motion, while the free-slip model predicts eastward and fault model predicts southeastward motion. Several other models predict westward motion for block 2 . In contrast, blocks in California have less than $20^{\circ}$ of variation in direction of motion, but velocity can vary by 3 or $4 \mathrm{~mm} / \mathrm{a}$ between the free, fault, and best fit models. A few blocks have velocities and azimuths that are relatively unaffected by modeling constraints, and the free/fault/best fit solutions will vary by less than $0.5 \mathrm{~mm} / \mathrm{a}$ and $5^{\circ}$ azimuth. Blocks 8, 20, 21, 25, and 29 fall into this category.

[72] For those blocks associated with the YSRP and the Yellowstone tectonic parabola, the constraints used in any particular model will have a greater effect on azimuth than on velocity (Figure 11). An example is block 13 in the ESRP, where the best fit velocity was $0.8 \pm 0.1 \mathrm{~mm} / \mathrm{a}$, while the free-slip and fault models had velocities of $0.5 \pm$ $0.1 \mathrm{~mm} / \mathrm{a}$ and $1.1 \pm 0.1 \mathrm{~mm} / \mathrm{a}$, respectively. Azimuths of motions were $263 \pm 2$ for the best fit model, $218 \pm 5$ for the fault model, and $202 \pm 7$ for the free-slip model. Thus the best fit model has a larger westward component of motion than the other two models, and the total motion is significantly different both in terms of uncertainties for individual velocity/azimuth parameters and in terms of the $F$ test, 


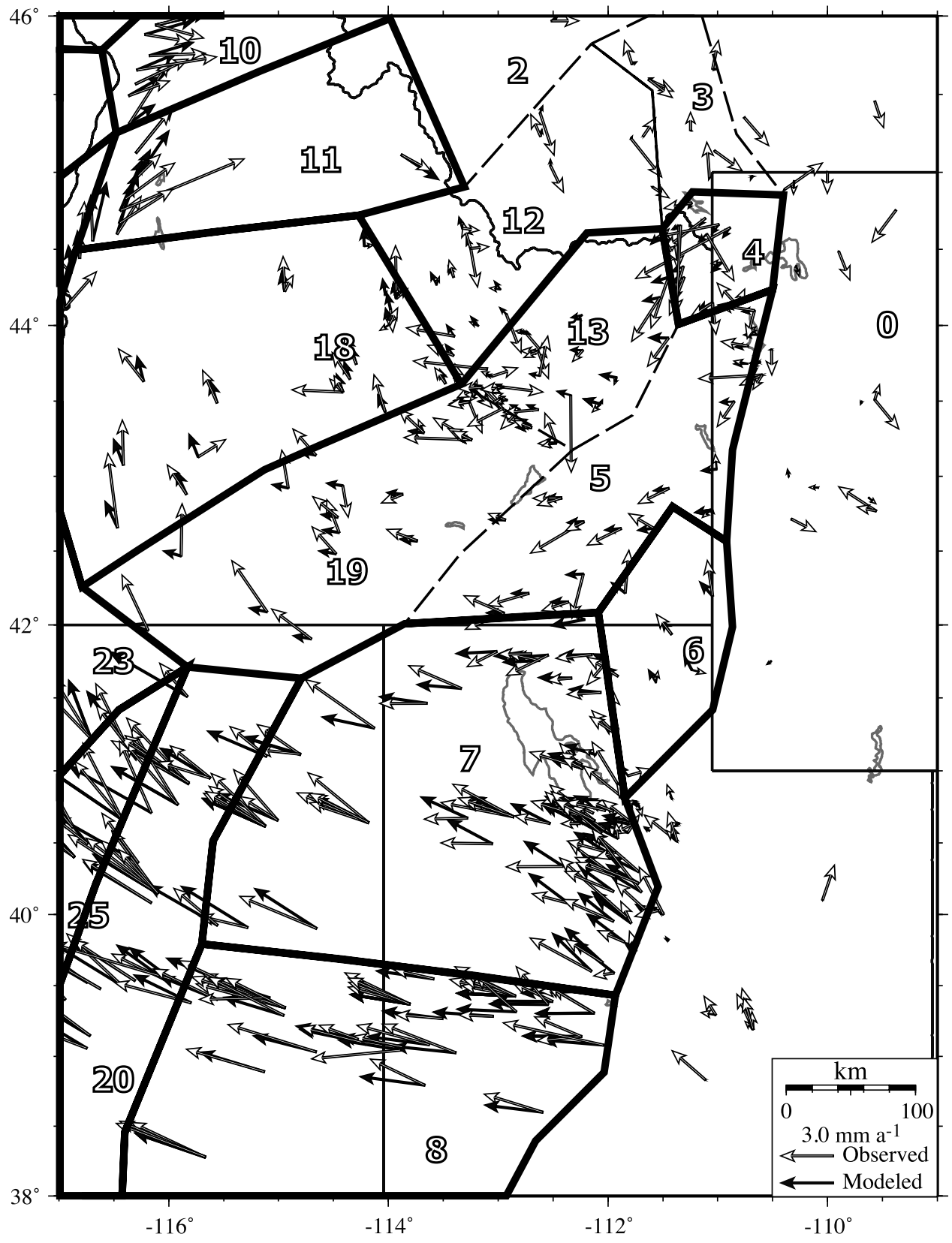

Figure 10. Map of observed (white) and modeled (black) velocities for the YSRP and eastern BasinRange. Modeled velocities are from the best fit model. Block numbers are included as white text with black outlines. Dashed lines represent boundaries between merged blocks. Observed velocities have been corrected for postseismic viscoelastic relaxation.

which calculated a $99.5 \%$ probability of difference between the best fit and fault model. However, Figure 11 shows a wide variation in the direction of motion for the ESRP (block 13), ranging from south to west. We interpret this as an effect of the transformation into the model reference frame of the postseismically corrected GPS data. The postseismic velocity field (Figure 6) has a strong southward component of $3-5 \mathrm{~mm} / \mathrm{a}$ in the YSRP region, and subtracting these velocities from the raw GPS data introduces a northward component. How much of this northward component is removed by the coordinate transformations will depend on modeling parameters of strain distribution and block grouping, with greater variations in the blocks near the center of regional rotation.

\section{Discussion}

\subsection{Effects of the Yellowstone Hot Spot on Deformation}

[73] Reconstructions of western U.S. tectonics for the last $33 \mathrm{Ma}$ predict that prior to the development of Yellowstone hot spot volcanism at $17 \mathrm{Ma}$, Idaho was relatively stable. Southern Idaho then underwent extension coinciding with the eastward propagation of the Yellowstone-Snake River Plain hot spot track [Atwater and Stock, 1988]. Active 

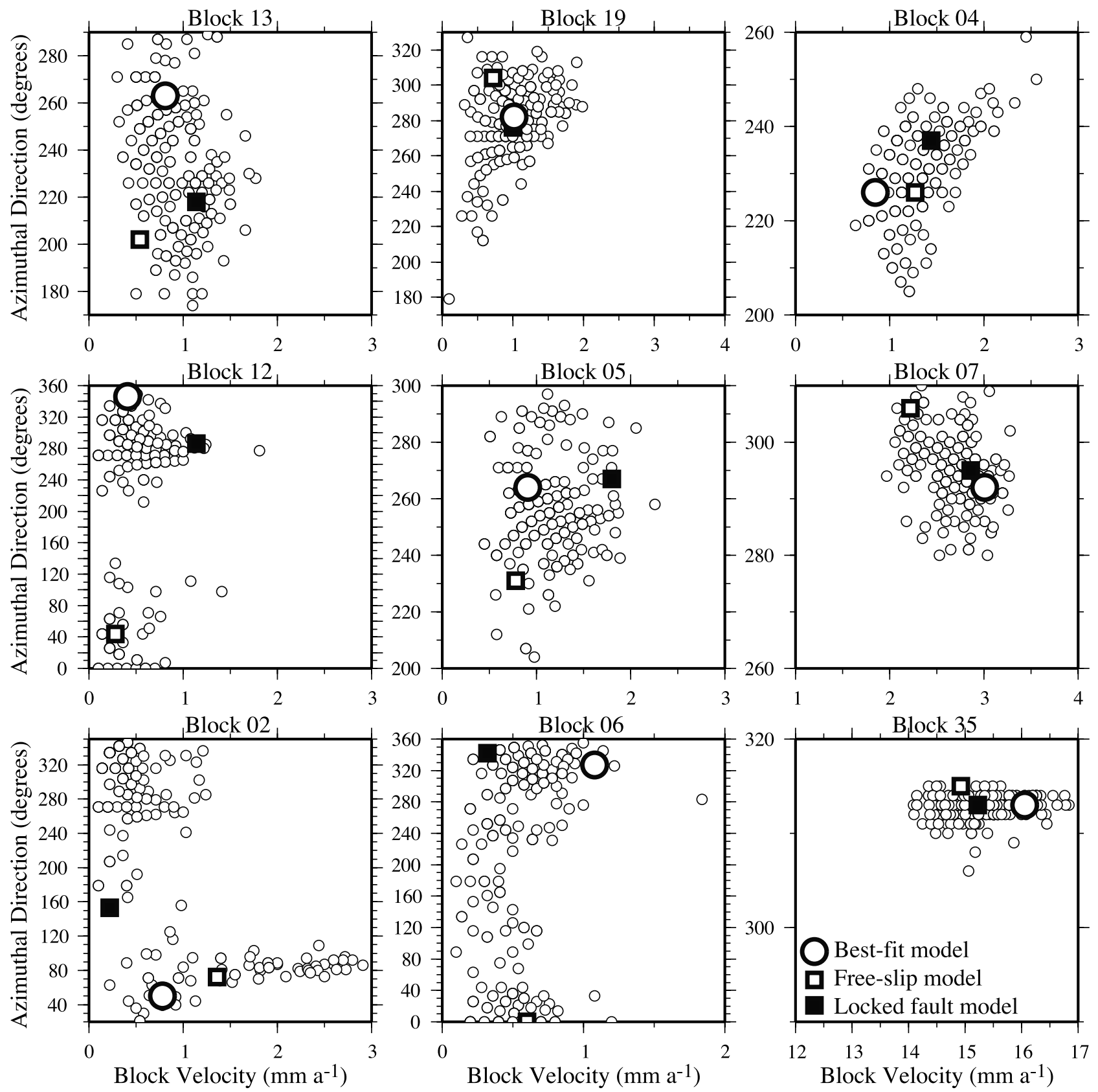

Figure 11. Plots of velocity versus direction for selected blocks. Small circles represent the velocity vector for a given block from one of the models examined in this study. The large white circle represents the velocity from the best fit model, while the white square corresponds to the free-slip model and the black square corresponds to the fault model.

faulting also shifted to the east in conjunction with the migration of volcanism [Anders et al., 1989; Smith and Braile, 1994]. This shift in earthquake activity and deformation resulted in the development of the Yellowstone tectonic parabola (Figure 1), with low seismicity within and immediately adjacent to the eastern Snake River Plain [Smith and Braile, 1994]. The seismic quiescence within the parabola has variously been attributed to strengthening of the crust through magmatic intrusion [Anders et al., 1989], accommodating extension through rifting [Parsons et al., 1998], and reduction of tectonic stresses through hot spot volcanism and ESRP subsidence [Puskas et al., 2007a]. The tectonic parabola correlates with changes in deformation rates and tectonic stresses [Puskas et al., 2007a], so that separate blocks were designated adjacent to the Yellowstone-Snake River Plain volcanic province to account for these changes (Figure 8).

[74] The best fit model predicts a component of differential motion between the ESRP and adjacent blocks to the north (Table 5). The difference in the magnitudes and directions of block velocities is very small: block 12 to the north of the ESRP experiences $0.41 \pm 0.02 \mathrm{~mm} / \mathrm{a}$ northward motion, while block 13, the ESRP block itself, experiences $0.8 \pm 0.1 \mathrm{~mm} / \mathrm{a}$ southwest motion. The absolute 
difference in velocities is less than half a millimeter per year. Block 5 in the south arm of the tectonic parabola experiences $0.9 \pm 0.1 \mathrm{~mm} / \mathrm{a}$ southwest motion but is constrained to share a pole of rotation with the ESRP.

[75] Chadwick et al. [2007] reported rates of 1.5 to $2.3 \mathrm{~mm} / \mathrm{a}$ north of the ESRP versus $2.8 \pm 0.3 \mathrm{~mm} / \mathrm{a}$ within the plain, a difference of up to $1.3 \mathrm{~mm} / \mathrm{a}$. Payne et al. [2008] report $0.9 \pm 0.3 \mathrm{~m} / \mathrm{a}$ for the ESRP and $1.7 \pm 0.2 \mathrm{~mm} / \mathrm{a}$ for the region north of the ESRP, but the northern GPS stations were concentrated primarily near the Lost River fault (Figure 7), a region that in our models appears to have increased velocities relative to the ESRP because of its distance from the center of regional rotation (Figures 5 and 8). However, our data included the postseismic corrections, which would have influenced the final solution by reducing GPS velocities by up to $1 \mathrm{~mm} / \mathrm{a}$ (from the 1959 Hebgen Lake earthquake; the 1700 Cascadia paleoearthquake can contribute to shifts in deformation as well), thus accounting for the higher velocities of Chadwick et al. [2007] when compared to the block velocities of this study. Other factors that can affect the block velocities are the transformation of the GPS velocities into the model reference frame, as well as scatter in the GPS data and strain within a block. Payne et al. [2007] also noted lower velocities to the north of the plain, while Puskas et al. [2007b] did not observe a notable difference, although the latter study only had two stations in the north arm of the parabola on which to base the comparison.

[76] Chadwick et al. [2007] proposed that the region north of the plain acted as a detachment zone between the YSRP and stable North America to the east. Our modeling results support this hypothesis, but we note that the block corresponding to the southern arm of the Yellowstone parabola moves southwest concurrently with the Snake River Plain, eliminating differential motion to the south. Additionally, block 12 (the north arm of the YSRP tectonic parabola) is located at the center of regional rotation, so that there is very little translation of the block with respect to stable North America. Westward and southwestward motion begins to the south of the center, with the blocks of the YSRP.

[77] The mechanism by which differential motion between the YSRP and northern blocks is accommodated is of importance to regional tectonics and earthquake hazards. Although there is no observed surface faulting parallel to the plain boundaries, some authors [Rodgers et al., 1990, 2002; Sparlin et al., 1982] have proposed a south dipping normal fault along the northern boundary to explain seismic observations but found no evidence for a corresponding north dipping fault at the southern boundary. In contrast, McQuarrie and Rodgers [1998] interpreted the dominant structural feature of the northern boundary to be downwarped Basin-Range crust based on observed flexure of fold hinges.

[78] Our model allows free motion along most of the eastern Snake River Plain boundaries because there are not enough GPS stations to adequately model a locked fault, though our model cannot rule out buried boundary faults. We note that the relative motions of the blocks would require oblique deformation along the north and south boundaries, implying shear stresses acting on the plain. This is supported by stress modeling, where the difference in gravitational potential energy between the eastern Snake River Plain and the northern Rocky Mountains produces shear stresses [Puskas et al., 2007a].

[79] An alternative hypothesis to block boundary faulting could be concurrent faulting of the YSRP tectonic parabola blocks with rifting in the plain [Parsons et al., 1998]. This would require numerous smaller blocks for our modeling that do not accumulate enough relative motion to trigger shear faulting at the Snake River Plain boundary. Large normal faults in the north arm of the Yellowstone tectonic parabola, along with seismic activity, suggest that strain is occurring in this region which is not resolved in the model.

[80] Most authors consider the eastern Snake River Plain to be a relatively rigid block [e.g., Anders et al., 1989; Smith and Braile, 1994] because the crystallization of ancient Yellowstone magma chambers that has been hypothesized to strengthen the midcrust by intrusion of a high-density, strong mafic sill that resists brittle fracture [Sparlin et al., 1982]. However, the presence of Holocene rift zones and basalt flows less than $15 \mathrm{ka}$ [Kuntz et al., 1982] argues that the Snake River Plain has undergone aseismic extension through fissure eruptions in Quaternary time [Parsons et al., 1998; Rodgers et al., 1990]. Prior GPS studies cannot rule out present-day strain within the plain or to the north of the plain [Payne et al., 2007; Puskas et al., 2007b], and the addition of new GPS data becoming available from Plate Boundary Observatory (PBO) should help resolve the strain rates in this region. Our results indicate that the differential motion is small $(<0.5 \mathrm{~mm} / \mathrm{a})$ at the northern boundary of the Snake River Plain, and that strain is occurring in the easternmost part of the plain (block 13).

\subsection{Basin-Range Kinematics}

[81] Basin-Range extension over the past $30 \mathrm{Ma}$ was accomplished by slip on hundreds of normal to oblique-slip faults, resulting in the distinctive topography of the tectonic province and a stretched crust up to $250 \mathrm{~km}$ wider than before [Dickinson, 2002; Sonder and Jones, 1999; Wernicke, 1992]. Presently, most extension occurs at the province boundaries and the central Nevada seismic zone [Eddington et al., 1987], but seismicity decreases to the north, making the identification of block boundaries there more difficult (Figure 1).

[82] The Basin-Range province in the western United States is typically divided into eastern and western halves [Eddington et al., 1987; McCaffrey, 2005]. There are several faults in Nevada with slip rates greater than $0.2 \mathrm{~mm} / \mathrm{a}$ [Haller et al., 2002], which can be construed as evidence that the western Basin-Range is actually composed of many small blocks. The presence of these faults, coupled with increases in strain magnitude and rotation, were used as the basis of subdivision in the western Basin-Range. The eastern Basin-Range in turn was subdivided into northern and southern subblocks to evaluate differences in deformation between the two (Table 5).

[83] Beginning in the eastern Basin-Range, the southern block (block 8) was modeled to be moving westward at $4.6 \pm 0.1 \mathrm{~mm} / \mathrm{a}$, notably faster than the motion in the northern part (block 7) of the province at $3.0 \pm 0.1 \mathrm{~mm} / \mathrm{a}$. The two parts of the Basin-Range did not share a common pole of rotation, and the division between them was chosen arbitrarily as a point between the southern extent of the 
Wasatch fault zone and the northern end of the Hurricane fault zone (Figure 8). We propose some possibilities to explain the discrepancy between the north and south subblocks.

[84] First, internal strain may be associated with unrecognized subblocks within one of the blocks, introducing a bias to the model. Northwest extension at the Wasatch fault zone contrasts with westward motion elsewhere in blocks 7 and 8 (Figure 10). This suggests that the Wasatch fault zone may be part of an intermediary block that introduces strain to block 7 and changes its direction of motion relative to block 8 . We also note that the Wasatch Front is not strongly affected by postseismic deformation, as the last large earthquake occurred over 400 years ago (W. L. Chang and R. B. Smith, unpublished manuscript, 2007), so local postseismic effects are not the cause of the difference.

[85] Another possibility is that the Colorado Plateau is not totally part of stable North America but is moving separately westward and rotating in response to extension across the Rio Grande rift in New Mexico and Colorado. Such motion could potentially increase velocities in southern Utah. Individual faults in the rift zone are listed as having slip rates of less than $0.2 \mathrm{~mm} / \mathrm{a}$, so any contribution of the rift zone is likely to be on the order of $0.2 \mathrm{~mm} / \mathrm{a}$ and hence very small.

[86] The $3.0 \pm 0.1 \mathrm{~mm} / \mathrm{a}$ westward motion of the northeastern Basin-Range agrees well with the GPS measurements of W. L. Chang and R. B. Smith (unpublished manuscript, 2007), who estimated $2.7 \pm 1.3 \mathrm{~mm} / \mathrm{a}$ across the 55-km-wide Wasatch fault zone, Utah. These results support the hypothesis that deformation is concentrated primarily on the Wasatch fault zone but not exclusively on the Wasatch fault itself, which has reported slip rates between 0.9 and $1.7 \mathrm{~mm} / \mathrm{a}$ (Table 4) [Chang and Smith, 2002]. Thatcher et al. [1999] measured an east-west extension rate of $2.8 \pm 0.5 \mathrm{~mm} / \mathrm{a}$ in central Utah at the boundary between the halves. Their results are consistent with our modeled motions of the northern part of the eastern Basin-Range. Our model incorporated strain for the eastern Basin-Range blocks and predicted modest extension of $6.5 \pm$ $0.6 \mathrm{n} \varepsilon / \mathrm{a}$, similar to low reported strain rates of $8 \pm 2 \mathrm{n} \varepsilon / \mathrm{a}$ [Hammond and Thatcher, 2004] to $10 \mathrm{n} \varepsilon / \mathrm{a}$ [Niemi et al., 2004].

[87] Our model begins partitioning the motions of western Basin-Range slip to the east of the central Nevada seismic zone (Figures 3 and 8). At this boundary velocities rapidly increase to $4.8 \pm 0.1 \mathrm{~mm} / \mathrm{a}$, and then at the central Nevada seismic zone velocities increase again to $5.2 \pm$ $0.1 \mathrm{~mm} / \mathrm{a}$. The two blocks representing the transition from the eastern to western Basin-Range, 20 and 25, were both found to have high extensional strain rates of $58 \pm 4$ and $45 \pm 4 \mathrm{n} \varepsilon / \mathrm{a}$, respectively. The preferred, best fit model did not require strain in the other western Basin-Range blocks, although a more complex model with a similarly low $\chi^{2}$ value incorporated strain into many of the western blocks. Therefore additional strain cannot be ruled out for the western Basin-Range.

[88] The rotation in the direction of motion from west to northwest can reasonably be expected to introduce shear as the westward component of motion decreases and the northward component increases, so that relative block motions become more parallel than divergent. The western
Basin-Range is normally considered extensional [Hammond and Thatcher, 2005], but shear deformation has also been recognized [Hammond and Thatcher, 2004; McCaffrey, 2005; Svarc et al., 2002].

[89] The southern Walker Lane seismic belt (where it merges with the eastern California shear zone) was modeled as a series of small blocks separated by strike-slip and oblique normal faults. Modeled blocks here are similar to those defined by McClusky et al. [2001] and McCaffrey [2005]. Block velocities in this region were all to the northwest and ranged from $8.0 \pm 0.3 \mathrm{~mm} / \mathrm{a}$ in block 30 to $11.8 \pm 0.2 \mathrm{~mm} / \mathrm{a}$ in block 29. While McClusky et al. [2001] modeled slip rates on the shear zone faults rather than calculate block velocities, McCaffrey [2005] modeled block velocities of $7.5 \mathrm{~mm} / \mathrm{a}$ and $5 \mathrm{~mm} / \mathrm{a}$ for the two blocks that correspond to blocks 29 and 30, respectively, in our model.

[90] The maximum velocities in southeast California (excluding the Sierra Nevada) were $11.1 \pm 0.2,11.3 \pm$ 0.2 , and $11.8 \pm 0.2 \mathrm{~mm} / \mathrm{a}$ and were observed in the southwestern blocks 29, 31, and 32. These velocities were comparable to the $12 \mathrm{~mm} / \mathrm{a}$ usually reported for measurements across the entire Basin-Range province [Dixon et al., 1995; Thatcher et al., 1999].

[91] We divided the Sierra Nevada-Great Valley block into three units based on earlier tests that indicated the possibility of distributed strain in the area from unmodeled deformation at the western boundary of the Sierra Nevada. Normally the Sierra Nevada is considered a single, rigid block [Dixon et al., 2000; McCaffrey, 2005], but large bounding faults such as the Garlock and San Andreas introduce strain at the boundary zones. The division of this block improved the $\chi^{2}$ parameter of our model as described previously. The northernmost block crosses the eastward projection of the Mendocino Triple Junction and thus a change in tectonic regime from transform motion to subduction [Kreemer and Hammond, 2007]. The transition is marked by a decrease in GPS velocities (Figure 5). The velocities of blocks 34 and 35 are $15.8 \pm 0.1$ and $16.1 \pm$ $0.1 \mathrm{~mm} / \mathrm{a}$, respectively, and their poles of rotation are within $10^{\circ}$ of each other (Table 5), so it could be argued that these blocks are moving together, even though our best fit model does not constrain them to do so.

[92] We note that blocks for the transition from BasinRange to Columbia Plateau are similar to those defined in other studies [Hammond and Thatcher, 2005, 2007], primarily because the same active faults were used to delineate blocks (Table 4). However, Hammond and Thatcher [2005] identify a block boundary at the California-Oregon border while we use a single block (block 26) that extends from northeast California to south central Oregon. While this boundary was not noted at the time we were constructing the block models, it is reasonable to infer a transition zone between $41^{\circ}$ and $42^{\circ}$ if we accept that the southernmost extent of subduction at Mendocino Triple Junction affects deformation in northern California.

\subsection{Columbia Plateau}

[93] Blocks in the Columbia Plateau region of the Pacific Northwest were divided on the basis of continuum kinematic modeling [Puskas et al., 2007a] because the absence of large, continuous faults and low seismicity in this region (Figure 1). As such, the resulting blocks do not coincide 


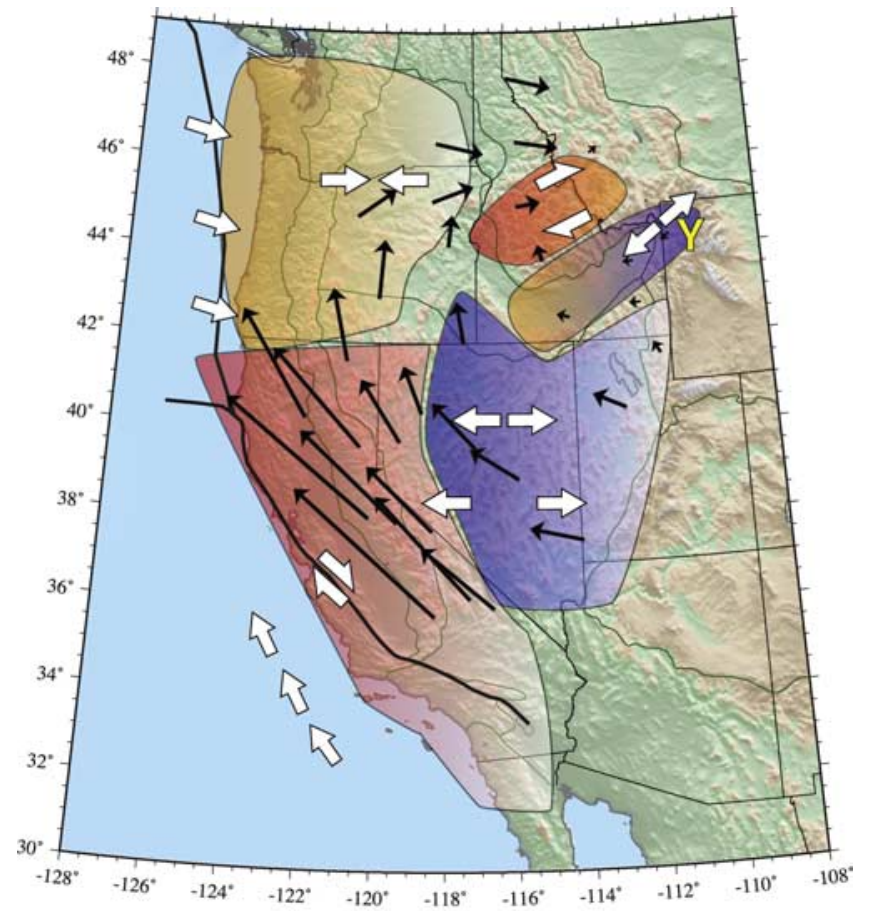

Figure 12. Summary of contemporary deformation of the western United States. Block velocities from our final model are shown as black arrows, while the large white arrows indicate the general sense of regional motion and are not to scale. Colored regions highlight deformation types: blue represents extensional domains, red represents shear domains, and orange represents contractional domains.

with local geographic provinces such as the Blue Mountains, High Lava Plains, or Okanogan Highlands. The model blocks will not necessarily align with structures such as the Olympic-Wallowa lineament or Yakima fold belt. Therefore our model of the Pacific Northwest is tentative and nonunique (Figure 8).

[94] McCaffrey et al. [2007] divided the Columbia Plateau into blocks that accommodate deformation through rotation. In the McCaffrey model, there are two blocks in southeast Oregon and one in northeast Oregon. The poles of rotation for these blocks are located nearby in northern Idaho and western Montana, so that velocities within each block varied from less than $1 \mathrm{~mm} / \mathrm{a}$ to $7 \mathrm{~mm} / \mathrm{a}$. Block motions were in the northwest to north direction.

[95] Like McCaffrey et al. [2007], our model divides the Columbia Plateau region into several large blocks, though our block boundaries do not align with the McCaffrey model because we used a different compilation of GPS data and included postseismic corrections. We use three blocks in southern Oregon and two blocks in northern Oregon (Figure 3). Our southern blocks are divided by large BasinRange faults in northeast California and southern Oregon, while the north Oregon blocks are allowed to move freely. Unlike McCaffrey's model, the average block velocity directions show pronounced rotation from northwest to north to east (Figure 8).

[96] The Columbia Plateau has been strongly affected by postseismic deformation following 1700 M9.1 Cascadia subduction zone earthquake [Pollitz et al., 2008]. In the
Pollitz model of postseismic viscoelastic flow, the presentday, local deformation from the Cascadia earthquake includes southward flow in southern Oregon, southwest flow in northern Oregon, and westward flow in Washington. By subtracting these postseismic velocities from our GPS velocities, we enhanced the north and east components of rotation in the Pacific Northwest.

\section{Conclusions}

[97] We have employed a microplate block modeling approach to analyze Yellowstone hot spot-related deformation and resolve a notable clockwise rotation of velocity vectors of the western U.S. interior. Deformation rates increased from east to west across the Basin-Range, reflecting westward extension with a transition to right-lateral oblique shear (Figures 8 and 12), and from north to south, reflecting greater deformation rates in the Basin-Range than the northern Rocky Mountains and Columbia Plateau. The southwest to west motion of the YSRP is one component of this larger pattern.

[98] The westward motion of the eastern Snake River Plain is driven by extension of the Yellowstone Plateau associated with the topographic hot spot swell [Puskas et al., 2007a, 2007b]. As the Yellowstone-Snake River Plain moves to the west, it allows opening in the northern BasinRange corresponding to the northern arm of the Yellowstone tectonic parabola and the northern ISB (Figure 12).

[99] South of the Yellowstone-Snake River Plain volcanic system, the direction of extension is to the west in the eastern Basin-Range, with the rate of extension increasing from north to south. The rotation from southwest to west occurs at the boundary of the Yellowstone tectonic parabola and eastern Basin-Range. Strain within block 7 in the eastern Basin-Range may indicate further partitioning of deformation at the boundary with stable North America and the Wasatch Front.

[100] In the western Basin-Range of central Nevada, block velocities change to a more northerly direction. Large historic earthquakes [Doser and Smith, 1989], increasing slip rates on Late Quaternary faults [Haller et al., 2002], and increased GPS velocities all suggest that this is an actively deforming region that accommodates motions through a complex network of faults. The blocks that correlate to the transition from eastern to western Basin-Range are predicted to be undergoing extensional strain (Table 6).

[101] In the Columbia Plateau, we model deformation with the motions of a few large blocks. This area was strongly affected by ongoing postseismic deformation from the M9.1 Cascadia paleoearthquake [Pollitz et al., 2008]. Correcting for postseismic deformation increased the northward and eastward components of block motions in this region, emphasizing the influence of postseismic deformation on contemporary motions.

[102] The paucity of GPS data in western and northern Idaho made it difficult to resolve block motions in this transitional region between the contractional regime of the Columbia Plateau and the extensional regime of the northern Basin-Range. This region includes the northern Rocky Mountains and appears to be moving eastward in northern Idaho and west central Montana (Figure 12), while the YSRP is moving west to southwest. The center of regional 
rotation is to the north of the YSRP (block 12) and likely experiences some shear from relative block motion.

[103] The clockwise pattern of regional contemporary rotation determined in this study and summarized in Figure 12 is consistent with reconstructions of western U.S. kinematics from Late Cenozoic tectonics [McQuarrie and Wernicke, 2005]. At $30 \mathrm{Ma}$, subduction of the Farallon plate's spreading ridge led to the formation of the Juan de Fuca plate and the inception of transform motion at the new PacificNorth America plate boundary. The northwest directed shear at the newly formed San Andreas fault system leads to complex shearing and rotation of blocks in the fault system [Atwater and Stock, 1988] as well as opening and westward extension of the Basin and Range due to gravitational collapse [Sonder and Jones, 1999; Wernicke, 1992]. Shear associated with Pacific-North America plate motions affects deformation at least as far inland as the western Basin and Range [Meade and Hager, 2005; Thatcher, 2003], while subduction of the Juan de Fuca plate below the overriding North America plate causes contraction in the Pacific Northwest [Zoback and Zoback, 1991; McCaffrey et al., 2000; Wang et al., 2003; McCaffrey et al., 2007].

[104] Our results suggest that the Yellowstone hot spot contributes to the western interior rotation, introducing contraction to the eastern Snake River Plain and possibly driving the plain's motion. The buoyant Yellowstone plume interacts with the overriding North America plate to produce a 300-km-wide topographic swell centered at the Yellowstone Plateau that has a high gravitational potential energy contributing to regional extension. This extension source has lead to the development of the Yellowstone tectonic parabola over the past $16 \mathrm{Ma}$, which consists of at least three blocks (blocks 3, 5, and 12). We find a minor amount $(<0.5 \mathrm{~mm} / \mathrm{a})$ of differential motion between the ESRP and north arm of the tectonic parabola, and insignificant differential motion relative to the south arm of the parabola. However, Late Quaternary normal faults in the parabola and rift zones in the plain are evidence that the blocks may need to be subdivided into smaller units to resolve deformation. The southwest to westward motion of the YSRP likely contributes to rotation and/or shear in the northern Rocky Mountains.

[105] Acknowledgments. We employed the block modeling program of Rob McCaffrey, who also kindly provided discussions of the methodology and results. We thank William Hammond, who shared his viscoelastic deformation models of the central Nevada seismic belt and reviewed this manuscript. Wu-Lung Chang provided postseismic viscoelastic velocities for the Hebgen Lake, Montana, and Borah Peak, Idaho, earthquakes as well as assistance with fault dislocation modeling and general feedback. Fred Pollitz shared his model of postseismic deformation of the western United States. Suzette Payne shared new GPS data on the eastern Snake River Plain. Greg Anderson answered questions about the EarthScope-PBO GPS data. Kathleen Haller provided feedback about the USGS Fault and Fold Database. Lucy Flesch provided useful discussions on the distribution and processes of western U.S. deformation. We also appreciate the comments and critical reviews of Tony Lowry, Jamie Farrell, Taka'aki Taira, Katrina DeNosaquo, Nadine McQuarrie, and an anonymous reviewer. Research support was provided by National Science Foundation Continental Dynamics program grants EAR 9725431, 0314298, 9725431, and 9316289 and the USGS NEHRP grants 02HQGR0098 and 07HQAG0027. Funding was also provided by the Brinson Foundation.

\section{References}

Anders, M. H., J. W. Geissman, L. A. Piety, and J. T. Sullivan (1989), Parabolic distribution of circumeastern Snake River Plain seismicity and latest Quaternary faulting: Migratory pattern and association with the Yellowstone hotspot, J. Geophys. Res., 94(B2), 1589-1621, doi:10.1029/JB094iB02p01589.

Anderson, L. W., L. A. Piety, S. S. Olig, and S. L. Forman (2003), Late Quaternary activity of the Canyon Ferry fault, Montana, Geol. Soc. Am. Abstr. Programs, 35(5), 11.

Atwater, T. (1970), Implications of plate tectonics for the Cenozoic tectonic evolution of western North America, Geol. Soc. Am. Bull., 81, 35133536, doi:10.1130/0016-7606(1970)81[3513:IOPTFT]2.0.CO;2.

Atwater, T., and J. Stock (1988), Pacific-North America plate tectonics of the Neogene Southwestern United State-An update, Int. Geol. Rev., 40, $375-402$.

Bennett, R. A., B. P. Wernicke, N. A. Niemi, A. M. Friedrich, and J. L. Davis (2003), Contemporary strain rates in the northern Basin and Range province from GPS data, Tectonics, 22(2), 1008, doi:10.1029/ 2001TC001355.

Blackwell, D. D., and M. C. Richards (2004), Geothermal map of North America, map, Am. Assoc. of Petrol. Geol., Tulsa, Okla.

Camp, V. E., and M. E. Ross (2004), Mantle dynamics and genesis of mafic magmatism in the intermontane Pacific Northwest, J. Geophys. Res., 109, B08204, doi:10.1029/2003JB002838.

Carlson, R. W., and W. K. Hart (1988), Flood basalt volcanism in the northwestern United States, in Continental Flood Basalts, edited by J. D. Macdougall, pp. 35-61, Kluwer Acad., Dordrecht, Netherlands.

Chadwick, D. J., S. J. Payne, T. Van Hove, and D. W. Rodgers (2007), Contemporary tectonic motion of the eastern Snake River Plain: A campaign global positioning system study, Tectonics, 26, TC6005, doi:10.1029/2005TC001914.

Chang, W. L. (2004), GPS (Global Positioning System) studies of the Wasatch Fault Zone, Utah, with implications for elastic and viscoelastic fault behavior and earthquake hazard, Ph.D. dissertation, 201 pp., Univ. of Utah, Salt Lake City.

Chang, W. L., and R. B. Smith (2002), Integrated seismic-hazard analysis of the Wasatch Front, Utah, Bull. Seismol. Soc. Am., 92(5), 1904-1922, doi: $10.1785 / 0120010181$.

DeNosaquo, K., and R. B. Smith (2009), Gravity-density and lithospheric strength models of the Yellowstone-Snake River Plain volcanic system, $J$. Volcanol. Geotherm. Res., in press.

Dickinson, W. R. (2002), The Basin and Range Province as a composite extensional domain, Int. Geol. Rev., 44, 1-38, doi:10.2747/00206814.44.1.1.

Dixon, T. H., S. Robaudo, J. Lee, and M. C. Reheis (1995), Constraints on present-day Basin-Range deformation from space geodesy, Tectonics, 14(4), 755-772, doi:10.1029/95TC00931.

Dixon, T. H., M. Miller, F. Farina, H. Wang, and D. Johnson (2000), Present-day motion of the Sierra-Nevada block and some tectonic implications for the Basin and Range province, North American Cordillera, Tectonics, 19(1), 1-24, doi:10.1029/1998TC001088.

Doser, D. I., and R. B. Smith (1989), An assessment of source parameters of earthquakes in the cordillera of the western United States, Bull. Seismol. Soc. Am., 79(5), 1383-1409.

Eaton, G. P. (1988), The Basin and Range province: Origin and tectonic significance, Annu. Rev. Earth Planet. Sci., 10, 409-440.

Eddington, P. K., R. B. Smith, and C. Renggli (1987), Kinematics of Basin and Range intraplate extension, in Continental Extensional Tectonics, edited by M. P. Coward, J. F. Dewey, and P. L. Hancock, Geol. Soc. Spec. Publ., 28, 371-392.

Flesch, L. M., W. E. Holt, A. J. Haines, L. Wen, and B. Shen-Tu (2007), The dynamics of western North America: Stress magnitudes and the relative role of gravitational potential energy, plate interaction at the boundary and basal tractions, Geophys. J. Int., 169, 866-896, doi:10.1111/j.1365-246X.2007.03274.X

Gan, W., J. L. Svarc, and W. H. Prescott (2000), Strain accumulation across the eastern California Shear Zone, J. Geophys. Res., 105(B7), 16,22916,236, doi:10.1029/2000JB900105.

Gourmelen, N., and F. Amelung (2005), Postseismic mantle relaxation in the Central Nevada Seismic Belt, Science, 310, 1473-1476, doi:10.1126/ science.1119798.

Haller, K. M., R. L. Wheeler, and K. S. Rukstales (2002), Documentation of changes in fault parameters for the 2002 National Seismic Hazard Maps-Conterminous United States except California, U.S. Geol. Surv. Open File Rep. 02-467, 34 pp.

Hammond, W. C. (2005), The ghost of an earthquake, Science, 310, 1440 1443, doi:10.1126/science.1121349.

Hammond, W. C., and W. Thatcher (2004), Contemporary tectonic deformation of the Basin and Range province, western United States: 10 years of observation with the Global Positioning System, J. Geophys. Res., 109, B08403, doi:10.1029/2003JB002746.

Hammond, W. C., and W. Thatcher (2005), Northwest Basin and Range tectonic deformation observed with the Global Positioning System, 
1999-2003, J. Geophys. Res., 110, B10405, doi:10.1029/ $2005 J B 003678$.

Hammond, W. C., and W. Thatcher (2007), Crustal deformation across the Sierra Nevada, northern Walker Lane, Basin and Range transition, western United States measured with GPS, 2000-2004, J. Geophys. Res., 112, B05411, doi:10.1029/2006JB004625.

Hammond, W. C., C. Kreemer, and G. Blewitt (2009), Geodetic constraints on contemporary deformation in the northern Walker Lane: 3 , central Nevada seismic belt postseismic relaxation, in Late Cenozoic Structure and Evolution of the Great Basin-Sierra Nevada Transition, Special Volume, Geol. Soc. of Am., Boulder, Colo., in press.

Holdahl, S. R., and D. Dzurisin (1991), Time-dependent models of vertical deformation for the Yellowstone-Hebgen Lake region, 1923-1987, J. Geophys. Res., 96(B2), 2465-2483, doi:10.1029/90JB02011.

Humphreys, E. D., and D. D. Coblentz (2007), North America dynamics and western U.S. tectonics, Rev. Geophys., 45, RG3001, doi:10.1029/ 2005RG000181

Jordan, B. T., A. L. Grunder, R. A. Duncan, and A. L. Deino (2004), Geochronology of age-progressive volcanism of the Oregon High Lava Plains: Implications for the plume interpretation of Yellowstone, J. Geophys. Res., 109, B10202, doi:10.1029/2003JB002776.

Jordan, M., R. B. Smith, C. Puskas, J. Farrell, and G. Waite (2005), The Yellowstone hotspot and relate plume: Volcano-tectonics, tomography, kinematics and mantle flow, Eos Trans. AGU, 86(52), Fall Meet. Suppl., Abstract T51D-1388.

Kreemer, C., and W. C. Hammond (2007), Geodetic constraints on areal changes in the Pacific-North America plate boundary zone: What controls Basin and Range extension?, Geology, 35, 943-946, doi:10.1130/ G23868A.1.

Kuntz, M. A., D. E. Champion, E. C. Spiker, R. H. Lefebvre, and L. A. McBroome (1982), The Great Rift and the evolution of the Craters of the Moon Lava field, Idaho, in The Cenozoic Geology of Idaho, edited by B. Bonnichsen and R. M. Breckenridge, pp. 423-437, Idaho Bur. of Mines and Geol., Moscow.

Langbein, J. O. (2003), Deformation of the Long Valley Caldera, California; Inferences from measurements from 1988 to 2001, J. Volcanol. Geotherm. Res., 127(3-4), 247-267, doi:10.1016/S03770273(03)00172-0.

McCaffrey, R. (2002), Crustal block rotations and plate coupling, in Plate Boundary Zones, Geodyn. Ser., vol. 30, edited by S. Stein and J. Freymueller, pp. 101-122, AGU, Washington, D. C.

McCaffrey, R. (2005), Block kinematics of the Pacific-North America plate boundary in the southwestern US from inversion of GPS, seismological, and geologic data, J. Geophys. Res., 110, B07401, doi:10.1029/ 2004JB003307.

McCaffrey, R., M. D. Long, C. Goldfinger, P. C. Zwick, J. L. Nabelek, C. K. Johnson, and C. Smith (2000), Rotation and plate locking at the southern Cascadia subduction zone, Geophys. Res. Lett., 27(19), $3117-$ 3120, doi:10.1029/2000GL011768.

McCaffrey, R., A. I. Qamar, R. W. King, R. Wells, G. Khazaradze, C. A. Williams, C. W. Stevens, J. J. Vollick, and P. C. Zwick (2007), Fault locking, block rotation and crustal deformation in the Pacific Northwest, Geophys. J. Int., 169, 1315-1340, doi:10.1111/j.1365-246X.2007. 03371.x.

McCalpin, J. P., and S. P. Nishenko (1996), Holocene paleoseismicity, temporal clustering, and probabilities of future large $(M>7)$ earthquakes on the Wasatch fault zone, Utah, J. Geophys. Res., 101(B3), 6233-6253, doi:10.1029/95JB02851.

McClusky, S. C., S. C. Bjornstad, B. H. Hage, R. W. King, B. J. Meade, M. M. Miller, F. C. Monastero, and B. J. Souter (2001), Present day kinematics of the eastern California shear zone from a geodetically constrained block model, Geophys. Res. Lett., 28, 3369-3372, doi:10.1029/ 2001GL013091.

McQuarrie, N., and D. W. Rodgers (1998), Subsidence of a volcanic basin by flexure and lower crustal flow: The eastern Snake River Plain, Idaho, Tectonics, 17(2), 203-220, doi:10.1029/97TC03762.

McQuarrie, N., and B. P. Wernicke (2005), An animated tectonic reconstruction of southwestern North America since $36 \mathrm{Ma}$, Geosphere, 1(3), 147-172, doi:10.1130/GES00016.1.

Meade, B. J., and B. H. Hager (2005), Block models of crustal motion in southern California constrained by GPS measurements, J. Geophys. Res., 110, B03403, doi:10.1029/2004JB003209.

Nash, B. P., M. E. Perkins, J. N. Christensen, D.-C. Lee, and A. Halliday (2006), The Yellowstone hotspot in space and time: $\mathrm{Nd}$ and $\mathrm{Hf}$ isotopes in silicic magmas, Earth Planet. Sci. Lett., 247(1-2), 143-156, doi:10.1016/j.epsl.2006.04.030

Nelder, J. A., and R. Meade (1965), A simplex method for function minimization, Comput. J., 7, 308-313.

Niemi, N. A., B. P. Wernicke, A. M. Friedrich, M. Simmons, and R. A. Bennett (2004), BARGEN continuous GPS data across the eastern Basin and Range province, and implications for fault system dynamics, Geophys. J. Int., 159(3), 842-862, doi:10.1111/j.1365-246X.2004.02454.x.

Nishimura, T., and W. Thatcher (2003), Rheology of the lithosphere inferred from postseismic uplift following the 1959 Hebgen Lake earthquake, J. Geophys. Res., 108(B8), 2389, doi:10.1029/2002JB002191.

Okada, Y. (1985), Surface deformation to shear and tensile faults in a halfspace, Bull. Seismol. Soc. Am. 75, 1135-1154.

Pancha, A., J. G. Anderson, and C. Kreemer (2006), Comparison of seismic and geodetic scalar moment rates across the Basin and Range province, Bull. Seismol. Soc. Am., 96(1), 11-32, doi:10.1785/0120040166.

Parsons, T., G. A. Thompson, and R. P. Smith (1998), More than one way to stretch: A tectonic model for extension along the plume track of the Yellowstone hotspot and adjacent Basin and Range Province, Tectonics, 17(2), 221-234, doi:10.1029/98TC00463.

Payne, S. J., R. McCaffrey, and R. W. King (2007), Contemporary deformation within the Snake River Plain and northern Basin and Range province, USA, Eos Trans. AGU, 88(23), Fall Meet. Suppl., Abstract G43B-06.

Payne, S. J., R. McCaffrey, and R. W. King (2008), Strain rates and contemporary deformation in the Snake River Plain and surrounding Basin and Range from GPS and seismicity, Geology, 36(8), 647-650, doi:10.1130/G25039A.1.

Perkins, M. E., and B. P. Nash (2002), Explosive silicic volcanism of the Yellowstone hotspot: The ash fall tuff record, Geol. Soc. Am. Bull., 114(3), 367-381, doi:10.1130/0016-7606(2002)114<0367:ESVO$\mathrm{TY}>2.0 . \mathrm{CO} ; 2$.

Pitt, A. M., C. S. Weaver, and W. Spence (1979), The Yellowstone Park earthquake of June 30, 1975, Bull. Seismol. Soc. Am., 69(1), 187-205.

Pollitz, F. F. (2001), Viscoelastic shear zone model of a strike-slip earthquake cycle, J. Geophys. Res., 106(B11), 26,541-26,560, doi:10.1029 2001JB000342.

Pollitz, F. F. (2003), Post-seismic relaxation theory on a laterally heterogeneous viscoelastic model, Geophys. J. Int., 155, 57-78, doi:10.1046 j.1365-246X.2003.01980.x.

Pollitz, F. F., P. McCrory, J. Svarc, and J. Murray (2008), Dislocation models of interseismic deformation in the western United States, J. Geophys. Res., 113, B04413, doi:10.1029/2007JB005174.

Press, W. H., S. A. Teukolsky, W. T. Vetterling, and B. P. Flannery (1992), Numerical Recipes in C, Cambridge Univ. Press, New York.

Puskas, C. M., R. B. Smith, L. M. Flesch, and K. Settles (2007a), Effects of the Yellowstone Hotspot on western U.S. Stress and Deformation, Eos Trans. AGU, 88(52), Fall Meet. Suppl., Abstract V51F-04.

Puskas, C. M., R. B. Smith, C. M. Meertens, and W. L. Chang (2007b), Crustal deformation of the Yellowstone-Snake River Plain volcanic system: Campaign and continuous GPS observations, 1987-2004, J. Geophys. Res., 112, B03401, doi:10.1029/2006JB004325.

Rodgers, D. W., W. R. Hackett, and H. T. Ore (1990), Extension of the Yellowstone Plateau, eastern Snake River Plain, and Owyhee plateau, Geology, 18, 1138-1141, doi:10.1130/0091-7613(1990)018<1138:EOTYPE $>2.3 . \mathrm{CO} ; 2$

Rodgers, D. W., H. T. Ore, R. T. Bobob, N. McQuarrie, and N. Zentner (2002), Extension and subsidence of the eastern Snake River Plain, in Tectonic and Magmatic Evolution of the Snake River Plain Volcanic Province, Idaho Geol. Surv. Bull. 30, edited by B. Bonnichsen, M. O. McCurry, and C. White, pp. 121-155, Idaho Geol. Surv., Moscow.

Savage, J. C. (1983), A Dislocation Model of Strain Accumulation and Release at a Subduction Zone, J. Geophys. Res., 88(B6), 4984-4996, doi:10.1029/JB088iB06p04984.

Savage, J. C., J. L. Svarc, and W. H. Prescott (1999), Geodetic estimates of fault slip rates in the San Francisco Bay area, J. Geophys. Res., 104(B3), 4995-5002, doi:10.1029/1998JB900108.

Savage, J. C., W. Gan, and J. L. Svarc (2001), Strain accumulation and rotation in the Eastern California Shear Zone, J. Geophys. Res., 106(B10), 21,995-22,007, doi:10.1029/2000JB000127.

Smith, R. B., and L. W. Braile (1994), The Yellowstone hotspot, J. Volcanol. Geotherm. Res., 61, 121-187, doi:10.1016/03770273(94)90002-7.

Smith, R. B., and R. L. Bruhn (1984), Intraplate extensional tectonics of the eastern Basin-Range: Inferences on structural style from seismic reflection data, regional tectonics, and thermal-mechanical models of brittleductile deformation, J. Geophys. Res., 89(B7), 5733-5762, doi:10.1029/ JB089iB07p05733.

Smith, R. B., and M. L. Sbar (1974), Contemporary tectonics and seismicity of the western United States with emphasis on the Intermountain Seismic Belt, Geol. Soc. Am. Bull., 85, 1205-1218, doi:10.1130/00167606(1974) $85<1205$ :CTASOT $>2.0$. CO 2

Smith, R. B., M. Jordan, B. Steinberger, C. M. Puskas, J. Farrell, G. P. Waite, S. Husen, W. L. Chang, and R. O'Connell (2009), Geodynamics of the Yellowstone hotspot and mantle plume: Seismic and GPS imaging, kinematics, mantle flow, J. Volcanol. Geotherm. Res., in press. 
Sonder, L. J., and C. H. Jones (1999), Western United States Extension: How the West was widened, Annu. Rev. Earth Planet. Sci., 27, 417-462, doi:10.1146/annurev.earth.27.1.417.

Sparlin, M. A., L. W. Braile, and R. B. Smith (1982), Crustal structure of the eastern Snake River Plain determined from ray trace modeling of seismic refraction data, J. Geophys. Res., 87(B4), 2619-2633, doi:10.1029/JB087iB04p02619.

Stickney, M. C., and M. J. Bartholemew (1987), Seismicity and late Quaternary faulting of the northern Basin and Range province, Montana and Idaho, Bull. Seismol. Soc. Am., 77(5), 1602-1625.

Svarc, J. L., J. C. Savage, W. H. Prescott, and A. R. Ramelli (2002), Strain accumulation and rotation in western Nevada, 1993-2000, J. Geophys. Res., 107(B5), 2090, doi:10.1029/2001JB000579.

Thatcher, W. (1995), Microplate versus continuum descriptions of active tectonic deformation, J. Geophys. Res., 100(B3), 3885-3894, doi:10.1029/94JB03064.

Thatcher, W. (2003), GPS constraints on the kinematics of continental deformation, Int. Geol. Rev., 45, 191-212, doi:10.2747/00206814.45.3.191

Thatcher, W., G. R. Foulger, B. R. Julian, J. Svarc, E. Quilty, and G. W. Bawden (1999), Present day deformation across the Basin and Range province, western United States, Science, 283, 1714-1718, doi:10.1126/science.283.5408.1714.

Waite, G. P., R. B. Smith, and R. M. Allen (2006), Vp and Vs structure of the Yellowstone hot spot: Evidence for an upper mantle plume, J. Geophys. Res., 111, B04303, doi:10.1029/2005JB003867.
Wallace, L. M., J. Beavan, R. McCaffrey, and D. Darby (2004), Subduction zone coupling and tectonic block rotations in the North Island, New Zealand, J. Geophys. Res., 109, B12406, doi:10.1029/2004JB003241.

Wang, K., R. Wells, S. Mazzotti, R. D. Hyndman, and T. Sagiya (2003), A revised dislocation model of interseismic deformation of the Cascadia subduction zone, J. Geophys. Res., 108(B1), 2026, doi:10.1029/ 2001JB001227.

Wernicke, B. (1992), Cenozoic extensional tectonism of the U.S. Cordillera, in The Geology of North America, vol. G3, The Cordilleran Orogen Conterminous U.S., edited by B. C. Burchfield, P. W. Lipman, and M. L. Zoback, pp. 553-581, Geol. Soc. of Am., Boulder, Colo.

Yuan, H., and K. Dueker (2005), Teleseismic P wave tomogram of the Yellowstone plume, Geophys. Res. Lett., 32, L07304, doi:10.1029/ 2004GL022056.

Zoback, M. D., and M. L. Zoback (1991), Tectonic stress field of North America and relative plate motions, in Neotectonics of North America, edited by D. B. Slemmons et al., pp. 339-366, Geol. Soc. of Am., Boulder, Color.

C. M. Puskas and R. B. Smith, Department of Geology and Geophysics, University of Utah, 115 S 1460 E, FASB 282, Salt Lake City, UT 84112, USA. (c.puskas@utah.edu) 